NBER WORKING PAPER SERIES

\title{
CURRENCY RETURNS, INSTITUTIONAL INVESTOR FLOWS, AND EXCHANGE RATE FUNDAMENTALS
}

\author{
Kenneth A. Froot \\ Tarun Ramadorai \\ Working Paper 9101 \\ http://www.nber.org/papers/w9101 \\ NATIONAL BUREAU OF ECONOMIC RESEARCH \\ 1050 Massachusetts Avenue \\ Cambridge, MA 02138
}

August 2002

We thank many people at State Street Corporation and State Street Associates for help in obtaining and interpreting data; Atindra Barua, Randy Cohen, Frank Diebold, Bernard Dumas, Jeff Frankel, Rich Lyons, Paul O 'Connell, Andrei Shleifer, Jeremy Stein, Tuomo Vuolteenaho, Joshua White, Seminar Participants at the Harvard International Economics Seminar, and Seminar Participants at the NBER Spring IFM Program Meeting for extremely useful comments and discussions; and the Department of Research at Harvard Business School for research support. All errors are our responsibility. The views expressed herein are those of the authors and not necessarily those of the National Bureau of Economic Research.

(C) 2002 by Kenneth A. Froot and Tarun Ramadorai. All rights reserved. Short sections of text, not to exceed two paragraphs, may be quoted without explicit permission provided that full credit, including (C) notice, is given to the source. 
Currency Returns, Institutional Investor Flows, and Exchange Rate Fundamentals

Kenneth A. Froot and Tarun Ramadorai

NBER Working Paper No. 9101

August 2002

JEL No. G11, G15, F21, F31

\begin{abstract}
We explore the interaction between exchange rates, institutional investor currency flows and exchange-rate fundamentals. We find that these flows are highly correlated with contemporaneous and lagged exchange rate changes, and that they carry information for future excess currency returns. This information, however, is not strongly linked to future fundamentals. Flows are important in understanding transitory elements of excess returns, which include short-run underreaction and long-run overreaction. However, flows have a zero or negative correlation with permanent components of excess returns. We find that measured fundamentals - not flows - seem important in understanding permanent elements of excess returns. We conclude that investor flows are important for understanding deviations of exchange rates from fundamentals, but not for understanding the long-run currency values.
\end{abstract}

Kenneth A. Froot

Graduate School of Business

Harvard University

Soldiers Field

Boston, MA 02163

and NBER

617-495-6677

kfroot@hbs.edu
Tarun Ramadorai

Graduate School of Business

Harvard University

Soldiers Field

Boston, MA 02163 


\section{Introduction}

In the standard finance paradigm, rational traders know the equilibrium price implications of public information instantly and effortlessly. Their main activity is to infer the information set imbedded in prices and then to rationally blend that information with their own signal. In practice, however, investors don't seem to do this. They spend little time or energy backing out the aggregate information set and weighing it against their own information. Instead, they spend considerable effort trying to understand what other investors might do. They seem to believe that exchange rates are driven by investor appetites, flows, and trading positions, and are only loosely connected with fundamentals. ${ }^{1}$

Much empirical evidence to date corroborates this view. Well-known work by Meese and Rogoff (1983) and many subsequent authors showed that contemporaneous, measured fundamentals do not explain exchange rate changes. In addition, considerable evidence has been building that institutional investor flows and trading positions matter. Evans and Lyons (2002) find that daily interdealer order flow explains an astonishing $60 \%$ of daily exchange rate changes and consequently argue that flows are the proximate cause of exchange rate movements. Rime (2000) finds that weekly flows obtained from the U.S. treasury help explain exchange rate movements. Others, such as Wei and Kim (1997) and Cai, Cheung, Lee and Melvin (2001) find that the positions of large traders explain currency volatility far better than do news announcements or measures of fundamentals. ${ }^{2}$

This flow-centric view - that investor flows cause exchange rate changes through private information which, when released, permanently and positively impacts exchange rate returns - is new. ${ }^{3}$ Evans and Lyons (2001) find no evidence that flows

\footnotetext{
${ }^{1}$ See Cheung and Chinn (2000) for survey evidence from practitioners on the importance of order flow information.

${ }^{2}$ There is some evidence - most notably from Mark (1995) - that fundamentals and exchange rates are better linked at longer horizons.

${ }^{3}$ For equities, the evidence supporting this view is more abundant, but mixed. Froot, O'Connell and Seasholes (2001) and Froot and Ramadorai (2001) find evidence across a broad number of countries that cross-border equity trades of institutional investors anticipate future equity index returns after controlling for lagged returns. Seasholes (2001) shows that foreign investors in two developing countries buy (sell) ahead of good (bad) news on individual stocks. Cohen, Gompers, and Vuolteenaho (2001) report that institutional investor's trades take advantage of underreaction in the prices of portfolios of US stocks, and therefore positively anticipate returns. However, there are also studies that come to the opposite conclusion. Choe, Kho, and Stulz (2001) find almost the reverse in Korea, in that foreign institutional investors' trades negatively anticipate future returns in individual stocks. Coval and Moskowitz (1999) find that
} 
predict returns, but argue that the strong daily contemporaneous correlation is a result of intraday information release that is important for exchange rate determination. Presumably, this information concerns future fundamentals, i.e., information that has long lasting impacts on excess returns. ${ }^{4}$ If this view we call it the 'strong flow-centric view' - holds, investor flows have permanent impacts on exchange rates.

There is a weaker version of this, which we refer to as the "weak flow-centric view'. It is that institutional flows contain information about deviations from fundamental values, rather than about fundamentals per se, and therefore have only temporary price effects. These effects may include liquidity and transaction demand price pressures, preference and other demand shocks, etc. They may play out over relatively short, or longer horizons. For example, several models try to explain short-term momentum, so that price changes predictably exhibit short-term positive autocorrelation along with long-term negative autocorrelation, patterns that have been widely reported in equity prices. Barberis and Shleifer (2002), Hong and Stein (1999), and Daniel, Hirshleifer, and Subrahmanyam (1998) argue that long-run reversals may result from trend-chasing investors following transitory rules of thumb.

Of course, contemporaneous positive correlation between flows and returns may not be evidence of either the strong or weak flow-centric views. Flows may passively respond to fundamental information, rather than reveal it, as in Brennan and Cao (1997). Institutions may tend to buy contemporaneously with or subsequent to positive currency changes. The flows may contain no information about fundamentals or about deviations from fundamentals that are useful for forecasting prices. For example, flows may respond with a lag to news and have no ability to predict future price changes. We call this third perspective the 'fundamentals-only view': flows have no ability to predict future exchange rates or future innovations in expected future fundamentals.

In this paper we attempt to assess these three views of investor flows: the strong flow-centric view, the weak flow-centric view, and the fundamentals-only view. In doing so, we explore the relationship between institutional investor purchases of foreign exchange, exchange rates, and basic measures of currency fundamentals. By calculating innovations in cumulated expected future funda-

US mutual fund stock selection is better when companies are geographically close to the fund manager.

${ }^{4}$ Evans and Lyons (2001) find evidence that news announcements effect exchange rates directly and indirectly through order flow. 
mentals, we can extract measures of permanent and temporary exchange rate shocks. This decomposition allows us to better understand how flows interact with both the fundamentals-driven permanent component and the transitory component of exchange rate returns.

Given that our high frequency foreign exchange flow data are relatively new, we first examine the behavior of currency flows and the contemporaneous bivariate relationship between flows and returns. Much as in Evans and Lyons (2002), we find this relationship to be quite strong. Our daily flows exhibit a correlation with daily excess returns of about $30 \%$. This is quite significant, but far smaller than that measured for the yen and DM by Evans and Lyons (2002). The differences may be due to our much longer and broader data sample and/or to the character of our flows. ${ }^{5}$ We also find that the flow/return correlation rises strongly with the horizon over which flows and returns are calculated. The correlations appear to peak at about $45 \%$ for major currencies at horizons of about a month. They then decline with horizon rapidly thereafter, falling to zero and then actually below zero at long horizons.

These preliminary facts suggest two things. First, unlike previous work on foreign exchange, there appear to be statistically and economically important non-contemporaneous correlations between returns and flows. Positive noncontemporaneous correlations are the only way to explain such large and significant changes in correlation with horizon. Either returns must be forecasting future flows (i.e., trend-chasing or positive-feedback trading), or flows must be forecasting future excess returns (i.e., anticipation), or both. Second, it would appear that the impact of flows on prices has a substantial transitory component. While the long-horizon decline in contemporaneous correlation is somewhat statistically imprecise, we find strong evidence that the correlation between flows and returns declines with horizon. Any impact of flows on returns is transitory in nature.

To go further, we need to account for the dynamic interaction of flows, returns, and measures of fundamentals and to extract measures of permanent exchange rate changes from the data. We use a vector autoregression and the CampbellShiller return decomposition to break excess currency surprises into a permanent component - shocks to the excess cashflow paid by a currency - and a transitory

\footnotetext{
${ }^{5}$ Naturally, the nature of the flow data may explain this difference in correlation. Our data come from the dollar value of trades of international institutional investors, whereas Evans and Lyons (2002) use the total count of interbank transactions made by the active counterparty.
} 
component - shocks to expected returns. ${ }^{6}$

Perhaps surprisingly, we find that expected return news (the transitory component of excess currency returns), has an estimated variance between 3 and 9 times as large as the variance of cashflow news (the permanent component of excess returns). Most of this variation comes from fluctuations in long-horizon expected returns; the variance of short-horizon expected returns is by comparison small, at between $10 \%$ and $50 \%$ of the variance of cashflow news. This follows from the fact that the small expected returns generated by fundamentals are highly persistent, so that a small change effectively cumulates over time and causes large capital gains or losses. Studies of stock index data by Campbell (1991) and others, also find that the variance of expected return news exceeds that of cashflow news. This is in contrast to studies of individual stocks by Vuolteenaho (2002) and Cohen, Gompers, and Vuolteenaho (2001), which use the same decomposition, but find that expected return news is considerably less variable than cashflow news.

We also find that, conditional on good cashflow news, currencies appreciate initially and then continue to earn excess returns over the short run (defined here as up to 30 trading days). In this sense, exchange rates exhibit shortrun underreaction. The magnitude of underreaction averages about $10 \%$ of the initial cashflow shock and is robust to the combination of flows and fundamentals we use to define cashflow shocks. This underreaction finding is quite similar in spirit to the momentum effects found in equity markets by Jegadeesh and Titman (1993) and Rouwenhorst (1998). ${ }^{7}$ In addition, we find that from a longerhorizon perspective, currencies overreact. Approximately one-third of the initial appreciation decays over time, with the decay principally due to a decline in real interest differentials. This finding is similar to overreaction results in the equity markets found by DeBondt and Thaler (1985) and Jegadeesh and Titman (2001), among others.

Next, we find substantial evidence of trend-chasing, in that, over the short-run, institutional investor flows respond positively to a surprise currency appreciation. On average, a $1 \%$ surprise appreciation results in a 0.37 -standard deviation inflow over 30 trading days, for the major currencies in our sample. For the same sample, over 30 days, a $1 \%$ appreciation generated entirely by cashflow news results in a

\footnotetext{
${ }^{6}$ For the derivation of the return decomposition in the context of stocks, see Campbell and Shiller (1988) and Campbell (1991).

${ }^{7}$ Equities, however, appear to have a considerably stronger underreaction effect. For individual stocks, Vuolteenaho (2002) finds underreaction equal to approximately $40 \%$ of cashflow shocks.
} 
1.17-standard deviation inflow. Both of these are consistent with the usual trendchasing interpretation. However, we also find that a $1 \%$ appreciation associated with a negative short-run expected return shock results in an outflow over 30 trading days. ${ }^{8}$

In other words, trend-chasing in flows occurs in response to improved perceptions of fundamentals. When an appreciation signals that short-run investment opportunities have declined, trend-reversing, not trend-chasing, occurs. Thus, institutional investors appear to exploit the short-run underreaction behavior of the exchange rate. ${ }^{9}$

However, this exploitation unravels for longer-term overreaction. We find that investor currency purchases are most sensitive to an appreciation generated by lower long-term expected returns; a $1 \%$ appreciation from this source results in a 0.60 - standard deviation inflow over 30 trading days, for the major countries. Investors seem to get the trees, but miss the forest, in that their inflows come in advance of short-term underreaction, but also in advance to what appears to be longer-term overreaction.

After accounting for the under- and over-reaction effects, we find strong evidence that current permanent exchange rate shocks are correlated with increases in current and expected future real interest differentials. Thus, much as in Mark (1995) and Clarida and Gali (1994), we find evidence contrary to Meese and Rogoff (1983): excess returns both forecast and respond contemporaneously to changes in observed fundamentals. ${ }^{10}$ However, because transitory exchange rate changes are relatively large, evidence for this correlation is not apparent in directly observed returns, which combine the transitory and permanent components. Only the permanent component of current exchange rate shocks appears to be positively correlated with innovations in fundamentals.

\footnotetext{
${ }^{8}$ This outflow is quite large - equivalent to 46 standard deviations - because a negative shock of $100 \mathrm{bp}$ to short-run expected returns is very large, given the much smaller standard deviation of expected returns.

${ }^{9}$ This result has been found by Cohen, Gompers and Vuolteenaho (2001) and Froot and Ramadorai (2001) in equity data. Rather than using a VAR to distinguish temporary and permanent effects, Froot and Ramadorai (2001) use closed-end country fund discounts and underlying fund NAVs. They find that an increase in NAV results in trend-chasing but that an increase in the closed-end fund discount results in trend-reversing.

${ }^{10}$ One distinction between our work and much previous long-horizon work on explaining exchange rates is that we use exchange rate changes in excess of the interest differential (i.e., excess currency returns rather than currency changes). Interest differentials usually account for only a small portion of return variation over short horizons, but over long horizons they are much more important.
} 
Taken together, these findings are not supportive of the strong flow-centric view. There is little evidence that flows proxy for innovations in cumulated expected future fundamentals. Flows do not forecast and are not forecasted by changes in real interest differentials, especially at long horizons. As a result, flows and measures of fundamentals are not very strongly related. Of course, this shouldn't be interpreted to mean that institutional investors pay no attention to fundamentals. Rather, changes in expected fundamentals appear to affect institutional investors and their counterparties rather symmetrically, creating few opportunities to trade profitably (based on our information set).

At short-horizons, the bulk of the evidence points toward the weak form of the flow-centric view. Flows contain limited information about short-term fundamentals, but mostly it appears that they contain information about follow-on short-term future demand. They do indeed contain some form of information, however, as they are useful for forecasting future excess returns. At longerhorizons, however, current and short-term inflows are contrarian indicators for returns. Current inflows predict long-horizon outflows and negative long-horizon excess returns. This is evidence that demand shocks and their associated price impacts are transitory. Finally, looking at the permanent shocks - which is the longest horizon in a sense - we find that a fundamentals-only story is most powerful. At long horizons, fundamental shocks and currencies are highly correlated, whereas flows and currencies are not.

The rest of this paper is organized as follows. Section 2 discusses the flow data and the relationship between contemporaneous flows and returns at various horizons. Section 3 introduces our VAR methodology and associated return decomposition. Section 4 then discusses the results and interpretation of our estimates. Section 5 concludes.

\section{The bivariate behavior of flows and returns}

\subsection{Foreign exchange transactions data}

Our cross-border FX transactions data come from State Street Corporation. State Street is the largest US master trust bank and one of the world's largest global custodians. It has approximately $\$ 7$ trillion of assets under custody. State Street records all transactions in these assets, including cash, underlying securities, and derivatives.

The foreign exchange data records transactions conducted in 111 currencies by 
13,230 funds. In our sample we filter out currencies classified by the IMF as being pegged or fixed as well as currencies whose transaction flows are relatively sparse on a daily basis. This leaves 19 country / currency areas: Australia, Canada, Euroland, Japan, New Zealand, Norway, Sweden, Switzerland, UK, Mexico, Indonesia, Korea, Philippines, Singapore, Taiwan, Thailand, Poland, India and South Africa. Pre-euro, Euroland flows represent aggregates across the 11 Euroland countries and they are paired with the Deutsche mark prior to the introduction of the euro.

Our sample begins January 1, 1994 and continues through February 9, 2001, covering 1,855 days for the 19 countries. There are 6,402,392 transaction records during this period, after cleaning and removing test transactions.

All transactions for a given trade date report future value amounts bought and sold. However, in order to aggregate trades, we need to calculate present values of these amounts. Our valuation methodology and additional data information can be found in Appendix I below.

Table 1 presents some descriptive statistics for the flow data. It shows the number of transactions per currency and the mean and standard deviation of absolute flows expressed in US dollars. Clearly, the transactions are heavily weighted toward the major currencies, both in terms of the number of trades and the mean absolute net daily flow. Within the major countries, the Euro and yen flows run at about three times the flows for Australia, Canada and Switzerland. Flows are considerably smaller for other countries, with the possible exception of Sweden and New Zealand.

Table 1 also reports flow and excess currency return autocorrelations. Flows are strongly autocorrelated, with autocorrelation coefficients averaging approximately $20 \%$ for the major currencies and even higher for some of the other Asian currencies. However, these autocorrelations are not as large as those observed in daily equity flows, perhaps because foreign exchange markets are more liquid than markets for individual equities. ${ }^{11}$ Return autocorrelations, as expected, are very low. Finally, Table 1 reports the correlation of daily flows with the log percentage change in each currency's exchange rate change against the US dollar. For most of the major currencies, these correlations are in the 30\%-40\% range.

\footnotetext{
${ }^{11}$ Froot, O'Connell, and Seasholes (2001) find that the daily autocorrelation of cross-border equity transactions (aggregated to a country level) are often $30 \%$ and higher.
} 


\subsection{A naive approach}

As a first step, we establish some basic facts about the behavior of flows and the correlation between currency flows and returns. We start with a simple regression of log foreign exchange excess returns on flows:

$$
r_{t, j}(K)=\hat{\alpha}+\hat{\beta} F_{t, j}(K)+\hat{\varepsilon}_{t, j},
$$

where $r_{t, j}(K)=\sum_{k=1}^{K} r_{t+1-k, j}$, is the $k$-period cumulated log excess return on currency $j, r_{t, j}$ is the excess return on the $j$ th currency measured against an

appropriate basket of currencies (see below), $F_{t, j}(K)=\sum_{k=1}^{K} f_{t+1-k, j} / \sigma\left(f_{j}\right)$ is the cumulated normalized US-dollar flow into currency $j$, and $\sigma\left(f_{j}\right)$ is a normalization of currency- $j$ flows based on own standard deviation. The normalization helps ensure comparability of flows across countries.

Our raw excess currency returns are measured against the US dollar. However, the US-dollar return against, say, the Swiss franc, is not really the appropriate exchange rate change to compare with net US dollar purchases of Swiss francs. This is because many of the flows into Swiss francs are funded - directly or indirectly - with Euros, pounds, and so forth. As a result, we might expect inflows to most strongly affect the value of the Swiss franc against some basket of currencies, where the basket weights would reflect the composition of currencies sold to finance the inflow. Unfortunately, it is impossible to observe the basket weights directly, since a single Swiss-Euro transaction may be effected through several transactions, with the US dollar serving in each of them as vehicle currency. As an alternative approach, we estimate the weights from the slope coefficients in a regression of excess Swiss franc returns on excess returns of the pound, euro, yen, and Australian dollar (where all excess returns are measured in terms of US dollars). We then use the residuals from this regression as our measure of excess returns on the Swiss franc. We employ this methodology for all currencies except those of Canada, the UK, Japan, Australia, and Euroland.

The regression in equation (2.1) allows us to measure the $\beta$ and $\rho$ (correlation coefficient) of returns and flows for any horizon, for any individual country, and for the entire panel. We employ overlapping return windows to maximize the amount of information available. Standard errors are estimated through a Monte Carlo procedure performed under the null hypothesis that flows and returns are i.i.d. and have the empirically-observed daily contemporaneous correlation. Appendix II contains a description of our Monte Carlo procedure. 


\subsection{Results from the naive approach}

Country-by-country estimates of equation (2.1) are reported in Table $2 .{ }^{12}$ Not surprisingly, Table 2 shows that flows are strongly correlated with exchange rate changes. Correlation coefficients in daily data average just under $30 \%$ and reach as high as $38 \%$ (for the pound). Table 2 also shows that the correlations increase for every currency from the daily to the 20-day horizon. The correlations reach as high as $53 \%$ for the euro and $56 \%$ for the yen. The increase in correlation with horizon is important. It requires substantial positive non-contemporaneous cross-correlation to be present. Indeed, the non-contemporaneous effects seem particularly strong, in that the correlations increase very substantially with horizon, especially for smaller countries such as Mexico, Poland, South Africa, Sweden, Singapore, and Taiwan.

Interestingly, as horizons increase beyond 20 or 60 days, the correlations fall for every currency, often by a large amount. Indeed, the correlations become negative for two of the currencies we deem to be 'major' (Euroland and Canada), and for 10 of the 19 currencies overall. While the statistical significance of each of these numbers is very much in doubt, the preponderance and magnitude of the decline in correlations suggests that much of the medium-term comovement of exchange rates with flows is not permanent. The positive association between flows and exchange rates appears to be largely transitory.

In addition to the correlation, it is interesting to examine the slope coefficients of returns projected on flows. A coefficient of 1.0 implies that a $\$ 100$ million dollar net inflow into a currency is on average associated with a 1 basis point appreciation. The coefficients for the majors on average indicate that a $\$ 100$ million dollar net inflow results in an appreciation of approximately 11.5 basis points. (This is about twice the size of the 5 basis point response found by Evans and Lyons (2002)). Euroland, Switzerland, and Canada have the lowest coefficients whereas Australia, Japan, and the UK have the highest. These numbers cannot properly be interpreted as measures of liquidity or of price impact because there is no presumption that causality runs from flows to returns. While many market microstructure models attempt to model price impact, relatively few treat flow as endogenous. ${ }^{13}$ Nevertheless, causality could run entirely or partly from prices to

\footnotetext{
${ }^{12}$ The country-by-country results in Table 2 do not use flows normalized by standard deviation. Under these circumstances, it is more informative to use the dollar value of individual country flows as the regressor.

${ }^{13}$ An important exception is Brennan and Cao (1997). They provide a model in which international investors purchase foreign assets in response to good news, thereby inducing a
} 
flows.

It is interesting to note that the slope coefficients show virtually no evidence of an increase with horizon. The increase in the correlation coefficient is therefore offset by an increase in the relative variability of flows. Because flows are positively autocorrelated and returns are less so, we should expect this effect. However, it is interesting that a complete offset of the change in correlation coefficient implies that exchange rates respond similarly to expected and unexpected flows.

Next, we investigate the longer-horizon features of the data in more detail. To gain additional degrees of freedom, we normalize flows as shown in equation (2.1) and stack the regression across our 19 exchange rates. This obviously gives us far more power at longer horizons. By using the full panel, we can measure holding horizons of up to 1,855 days, or almost 7.5 years. The results for the flow-return correlation coefficient are depicted in Figure 1 for both the major currencies and the full sample. The $x$-axis is in log terms, running from 1-day horizons $\left(10^{0}\right.$ days $)$ to 1,855 -day horizons (greater than $10^{3}$ days). The figure shows the point estimates and $90 \%$ confidence intervals. The confidence intervals are derived from the Monte Carlo exercise described in Appendix II. They are computed under the null hypothesis that flows and returns are each i.i.d., with a daily contemporaneous correlation given by the actual observed daily panel correlation.

The results in Figure 1 provide very strong statistical evidence of both patterns observed more tentatively in the country-by-country regressions. First, there is statistically significant non-contemporaneous positive correlation of flows and returns at horizons from 2 to 70 trading days for the majors and about 3 to 40 trading days for all currencies. Note that the standard-error bands in the figure are drawn based on the observed contemporaneous correlation of one-day flows and returns (28\% for the majors and 9\% for all currencies). Transcendence of these bands therefore indicates statistically significant non-contemporaneous correlation. Thus, at medium-term horizons, flows must either positively anticipate returns or positively trend-follow them.

Second, beyond these medium-term horizons, the overall correlation begins to fall, crossing zero at about 300 trading days for both the major currencies and the entire sample. This is the point where the positive daily correlation is just offset by the negative non-contemporaneous correlations. Put differently, at a horizon of about 1.2 years, there is approximately no correlation between currency flows

positive correlation between current flow and return. 
and returns. At these horizons, the non-contemporaneous correlation is already statistically negative since the dashed line crosses the lower confidence bound. Furthermore, at horizons of about 800-1,000 days, the data show a statistically negative overall flow/return correlation. That is, in the full sample of currencies, the dashed line falls beneath the lower confidence bound by approximately the magnitude of the one-day flow/return correlation.

This suggests that currencies that rose in the medium term amidst inflows declined over the longer term back to where they began, and perhaps even further. Naturally, much of this negative correlation is being generated by the cross-section, rather than the time series aspects of the panel. In the limit, at the longest horizon we can estimate, 1,855 days, the result is purely cross-sectional. Countries receiving larger net flows over this horizon tend to earn smaller excess returns than those receiving smaller net flows.

One interpretation of these facts is that the impact of flows on currencies is transitory. Any information contained in flows is not about fundamentals

per se. By the law of iterated expectations, and assuming that deviations of exchange rates from levels implied by fundamentals are stationary, innovations in fundamentals have permanent exchange rate impacts.

Overall, it is clear that there is important predictability of returns by flows and/or of flows by returns. Moreover, this predictability is complex, in that it must have substantially different features at short vs. long horizons. Does this imply positive predictability of returns at short horizons and negative predictability at long horizons? Is it instead evidence that flows, not returns, are predictable in this way? To explore this, we need a more sophisticated platform to disentangle the implications of the naive approach in Figure 1. We will also need to add some measures of fundamentals into the estimation. At longer-horizons, it is especially important to understand the extent to which flows contain information about fundamentals and vice versa.

\section{VAR specification}

In the analysis so far, we have focused on the simple bivariate relationship between flows and FX returns. We now want to explore how flows interact with both returns and fundamentals.

In order to flesh out these interactions, we need to condition exchange rate changes on innovations to fundamentals and to flows. We begin with a standard VAR which includes a return equation, a flow equation, and at least one other 
equation in variables that are useful for forecasting returns and future currency cashflows.

$$
z_{t}=\Gamma z_{t-1}+u_{t}
$$

As usual, this specification is general as to the number of lags in the VAR, as $z_{t}$ and the companion matrix, $\Gamma$, allow for arbitrary lag lengths (see Campbell and Shiller, 1987). We will assume that $\Gamma$ is constant across currencies, and that the covariance matrix, $E\left[u_{t} u_{t}^{\prime}\right]=\Sigma$, allows for contemporaneous correlation of the residuals across currencies.

In our application, the equations include an excess return equation, a real interest rate differential equation, a real exchange rate equation, and a flow equation. We also considered breaking up the real interest differential equation into two equations of interest differentials and inflation differentials, in order to allow the dynamics of the processes to differ. We include these equations to pick up several aspects of exchange rate behavior. First, both interest differentials and real exchange rates are widely noted as informative about excess returns. Second, there is evidence that flows and long-run real interest differentials help explain real exchange rates.

The VAR impulse response allows us to identify how shocks affect cumulative expected innovations. Specifically, the innovation in cumulative expected future changes $k \geq 1$ periods forward is given by $\Phi(k) u_{t}$, where

$$
\Phi(k)=\left(\Gamma-\Gamma^{k+1}\right)(I-\Gamma)^{-1} .
$$

We pick out cumulated expected changes in any VAR variable by premultiplying by the appropriate selection vector. For example, the innovation in the cumulated expectations of the first variable, excess foreign exchange returns, is given by $e 1^{\prime} \Phi(k) u_{t}$ where

$$
e 1^{\prime}=\left[\begin{array}{llll}
1 & 0 & \ldots & 0
\end{array}\right]
$$

Analogously, the innovation in cumulated expectations of the second variable, currency inflows, is given by $e 2^{\prime} \Phi(k) u_{t}$, where $e 2^{\prime}=\left[\begin{array}{llll}0 & 1 & \ldots & 0\end{array}\right]$.

The total impulse response from a shock to exchange rate returns is the sum of the innovation in cumulative expected future return changes, $e 1^{\prime} \Phi(k) u_{t}$, plus the shock itself, $e 1^{\prime} u_{t}$, or 


$$
e 1^{\prime} \Psi(k) u_{t} \equiv e 1^{\prime}(\Phi(k)+I) u_{t}
$$

where $\Psi(k)=\Phi(k)+I$.

As in the previous section, horizons will be important here. For infinite horizons, we can express the cumulative innovation matrices as $\Psi=\Psi(\infty)$ and $\Phi=\Phi(\infty) .{ }^{14}$ Also the cumulative innovations beginning in period $k+1$ can be expressed as $\Psi-\Psi(k)$ and $\Phi-\Phi(k)$, respectively.

\subsection{Campbell return decomposition}

We can go further with the interpretation of the total impulse response of excess returns using the return decomposition of Campbell and Shiller (1988) and Campbell (1991). To see this, note that the log excess return on foreign exchange is equal to the change in the log real exchange rate plus the log real interest rate differential:

$$
r_{t+1}=\left(\delta_{t+1}-\delta_{t}\right)+\left(i_{t}^{*}-\pi_{t+1}^{*}\right)-\left(i_{t}-\pi_{t+1}\right),
$$

where $\delta$ is the value of the log real exchange rate defined in terms of USD per unit of foreign exchange, $i$ and $i^{*}$ are, respectively, the continuously compounded one-period USD and foreign currency riskless interest rates, and $\pi$ and $\pi^{*}$ are analogous continuously compounded rates of inflation.

Solving this equation forward, subject to expectations based on time-t information, we have that the log real exchange rate is the sum of expected future real interest differentials (e.g., real cash flows), less cumulated log expected excess returns:

$$
\delta_{t}=\sum_{i=1}^{\infty} E_{t}\left(d_{t+i}-r_{t+i}\right),
$$

where $d_{t}$ is the real interest differential between times $t-1$ and $t, d_{t}=i_{t-1}^{*}-$ $\pi_{t}^{*}-\left(i_{t-1}-\pi_{t}\right)$. In solving equation (3.5) forward, we impose the terminal condition $\lim _{i \rightarrow \infty} E_{t} \delta_{t+i}=0$, assuring convergence. This implies that, in the long run, purchasing power parity holds in expectation. An appreciation away from purchasing power parity can occur either because of high future real interest differentials or low required returns. This real appreciation decays over time, either

\footnotetext{
${ }^{14}$ Here, $\Phi=\Phi(\infty)=\Gamma(I-\Gamma)^{-1}$, and $\Psi=\Psi(\infty)=\Phi(\infty)+I$, as before.
} 
through a decay in the cumulated future real interest differential (due to negative innovations in cumulated future nominal interest rates or positive innovations in cumulated future expected inflation), or through an increase in expected future returns.

Using equations (3.5) and (3.6), we can write the unexpected one-period return as the sum of the innovations in expected future real interest differentials and excess currency returns:

$$
r_{t+1}-E_{t}\left(r_{t+1}\right)=\left(E_{t+1}-E_{t}\right) \sum_{i=1}^{\infty}\left(d_{t+i}-r_{t+1+i}\right) .
$$

This equation differs from Campbell's in that the return decomposition implied by equation (3.5) is exact, not approximate. The approximation in the case of equities occurs because dividends are additive to cash flow, so that log returns can be written in terms of log prices and log dividends only by approximation. In the exchange rate example, however, cash flow accretion (interest) occurs proportionally, and, therefore, the log return is exactly additive in log real interest differentials and log real exchange rate changes. An alternative interpretation for equation (3.7) is that it represents a decomposition of excess currency returns into a permanent and transitory component as in Beveridge and Nelson (1981). Changes in future expected excess returns generate temporary fluctuations, as the current impact of a future change creates an equal and opposite movement in the currency.

Examining equation (3.6) above, we note the decomposition of the real exchange rate into cumulated future real interest differentials and future expected return innovations holds with perfect foresight. It also holds under expectations formed rationally subject to any information set, since equation (3.7) involves application of the law of iterated expectations. We therefore have considerable leeway in positing variables that affect expected returns and/or cashflows.

Equation (3.7) expresses unexpected excess currency returns as the difference between "cashflow" news and "expected-return" news. Cashflow news is the innovation in the present value of future interest differentials, $\left(E_{t+1}-E_{t}\right) \sum_{i=1}^{\infty} d_{t+i}$. It can be thought of as the excess currency return that would prevail at a given time if expected future currency returns were held constant. Expected return news, which is $\left(E_{t+1}-E_{t}\right) \sum_{i=1}^{\infty} r_{t+1+i}$, is the innovation in the exchange rate that is attributable to a change in required returns, holding expected future cashflows constant. Naturally, an increase in future expected returns, given cashflows, results in a current depreciation. Defining $\nu_{c f, t}=\left(E_{t+1}-E_{t}\right) \sum_{i=1}^{\infty} d_{t+i}$ and 
$\nu_{e r}=\left(E_{t+1}-E_{t}\right) \sum_{i=1}^{\infty} r_{t+1+i}$, equation (3.7) can therefore be written as:

$$
e 1^{\prime} u_{t}=\nu_{c f, t}-\nu_{e r}
$$

A surprise appreciation of a currency is associated either with an increase in expected future real interest differentials given required returns, or a decrease in required future returns given real interest differentials.

The decomposition in equation (3.8) is useful for several purposes. First, it is interesting in itself to perform the simple variance decomposition of excess currency returns into cashflow and expected return components. In equities, Campbell and Shiller (1988) and Campbell (1991) decompose the variance of aggregate returns, finding that expected return news dominates cashflow news in the postwar period. Vuolteenaho (2002) performs a similar exercise for individual stocks. However, he finds that for individual stocks, expected return news is less than half as large as cashflow news. Whereas information about expected returns is dominant for equity aggregates, it is relatively less important for individual stocks. The relationship between expected return volatility and cashflow volatility is less studied for currencies. Campbell and Clarida (1987) decompose excess returns into changes in the long-run real exchange rate and long-run real interest differentials. However, they assume that changes in expected returns are perfectly correlated with changes in real interest differentials.

Second, the decomposition yields an alternative interpretation of the total impulse response for returns from the VAR, $e 1^{\prime} \Psi u_{t}$. According to the decomposition in equation (3.8) above, the permanent component of currency surprises, cashflow news, is $\nu_{c f, t}=e 1^{\prime} u_{t}+\nu_{e r, t}$. Expected return news, $\nu_{e r}$, emerges directly from the VAR, we have that $\nu_{e r, t}=e 1^{\prime} \Phi u_{t}$. This then implies that cashflow news is given by

$$
\nu_{c f, t}=e 1^{\prime} \Psi u_{t}
$$

i.e., the total return impulse response. In other words, cashflow news is the exchange rate innovation that occurs when expected returns are held constant; it is observed by adding back all future expected return innovations to the current return shock.

\subsection{VAR relationships}

Using the VAR and the return decomposition, we address a number of questions about the relationship between currencies, flows, and fundamentals. The VAR is 
also very well suited to address these questions at any horizon we choose. This is particularly important given the striking role horizon appears to play in the flow/return evidence above.

First, how important are expected return shocks vs. cashflow shocks in the decomposition of the variance of currency excess returns? The variance of excess returns is given by

$$
\sigma_{f x}^{2}=\sigma_{c f}^{2}+\sigma_{e r}^{2}-2 \rho_{c f, e r} \sigma_{c f} \sigma_{e r}
$$

or, equivalently, in the notation above,

$$
e 1^{\prime} \Sigma e 1=e 1^{\prime} \Psi \Sigma \Psi^{\prime} e 1+e 1^{\prime} \Phi \Sigma \Phi^{\prime} e 1-2 e 1^{\prime} \Psi \Sigma \Phi^{\prime} e 1 .
$$

When useful, we can further decompose the right-hand side by distinguishing between cumulated innovations in expected returns, $\Phi$, over short horizons $(k$ days or less) and long horizons ( $k+1$ days on).

Second, the variance decomposition in equation (3.10) can be used to answer the question: how much does the currency move given a $1 \%$ cashflow shock? Vuolteenaho (2002) interprets this coefficient as a measure of overreaction. That is, if the currency appreciates by less than 1\%, there is "underreaction" (i.e., the cashflow shock is greater than the currency innovation because of a positive correlation with future expected returns); if the currency appreciates by more than $1 \%$, there is "overreaction" (e.g., the cashflow shock is smaller than the currency innovation because of a negative correlation with future expected returns). From the decomposition in equation (3.11), the overreaction coefficient is given by:

$$
\beta_{\text {over }}=1-\frac{\left(e 1^{\prime} \Phi(k) \Sigma \Psi^{\prime} e 1\right)}{e 1^{\prime} \Psi \Sigma \Psi^{\prime} e 1}-\frac{\left(e 1^{\prime}(\Phi-\Phi(k)) \Sigma \Psi^{\prime} e 1\right)}{e 1^{\prime} \Psi \Sigma \Psi^{\prime} e 1}
$$

Given that cashflow shocks are the residual from a model of expected returns, any measurement error in that model biases the residuals toward the simple excess return. This creates a bias in $\beta_{\text {over }}$ toward 1 , instead of the typical bias toward zero.

Third, once we have determined the extent to which currencies under and/or overreact, we can inquire about the flow response. For example, suppose that the currency initially underreacts to cashflow news. We want to know whether the flows exploit this underreaction by buying in the short run. Suppose, however, 
that over the longer run, currencies overreact to cashflow news. At some horizon, the currency must cease appreciating and begin depreciating. Do the flows also exploit this overreaction, by eventually beginning to sell?

Finally, the estimates from the earlier, naive approach are related to those derived in this section. We clarify that relationship in Appendix III below.

\subsection{The relationship of flows with returns}

There are many ways to look at the data which emerge from the VAR and return decomposition. Table 3 provides a relatively parsimonious means of summarizing the comovement of flows and returns. The first row shows innovations in flows. The second row reports the present value of cumulated flow innovations through period $k$, where expected flows are computed from the VAR. The third row is similar, but cumulates only those innovations from period $k+1$ on. The fourth row is the sum of the previous three rows. The four columns are analogous, reporting the excess return shock, and its components, short-term expected return innovations, long-term expected return innovations, and the sum of the previous three. Notice that the fourth (and last) column also corresponds to the cashflow innovations in equation (3.8).

Table 3 incorporates many of the relationships discussed in the literature. First is the contemporaneous comovement of unexpected flow and return, $e 1^{\prime} \Sigma e 2$, often termed "price impact". We use that term for convenience only; we do not presume or require that causality runs in any particular direction. Second, is the anticipation effect, the covariance of the present value of cumulated expected return innovations and flows. Here there is the presumption of causality - in at least in the sense of Granger - running from flow to return. We report both shortterm (ST) and long-term (LT) anticipation effects. Third, the decomposition allows investigation of what we call "total price impact", i.e., the contemporaneous comovement of the exchange-rate change holding expected returns constant with unexpected flow.

The second and third lines relate the short-term and long-term innovations in the present value of expected future flows to current excess returns, shortand long-term expected return innovations, and cashflow innovations. In the first column, the standard term, "trend chasing," signifies the response of future expected flow innovations to current unexpected returns. While trend chasing is easy to measure, it is a somewhat blunt way of characterizing investor flows. We decompose trend chasing into the covariance of expected future flow innovations 
with expected return innovations (ST and LT "expectational comovement") versus the total flow response to changing cashflows ("cashflow chasing").

To scale the covariances in Table 3 while preserving additivity across rows and columns, we divide each measure by $\left(e 1^{\prime} \Sigma e 1 e 2^{\prime} \Sigma e 2\right)^{1 / 2}$, the product of the innovation standard deviations.

\section{VAR estimation}

Several issues arise in the implementation of our VAR at a daily frequency. First, since we are interested in lower-frequency dynamics, we want to add many lags. In order to determine the optimal lag-length, we run a model selection test using the Schwartz Bayes criterion. The results indicate that 65 daily lags were optimal in our four variable VAR. To ensure tractability and better out-of-sample behavior, we then impose continuity restrictions on the coefficients. Specifically, we aggregate lags of 2-5, 6-10, 11-21, 22-43, and 44-65 days, essentially forcing the coefficients within each aggregation to be identical. In this way, we hope to detect predictability on a monthly frequency, in a manner similar to studies that might run VARs on monthly data only. The second issue concerns the measurement of our interest differentials. Overnight interest rates are frequently not observed. As a compromise, we use weekly rates, effectively assuming that the term structure is flat between one day and one week.

Third, inflation data are monthly. Given that there is no good fix for this, we simply assume that monthly inflation occurs smoothly through the month. Since inflation shocks are highly persistent, this is not a terrible assumption. However, if, for example, there is a once-and-for-all mid-month surprise increase in the domestic price level, we will not correctly match the timing of the inflation shock with the daily data on exchange rates, flows, and interest rates. With respect to inflation shocks, we will therefore blur cause and effect in the sense of Granger. In order to better align the CPI's with their announcement dates, we lag their entry into the information set by two weeks.

Fourth, we restrict the coefficients on lags past the first of the real exchange rate to be zero in our VAR. There is no need to include these extra terms; they do not affect the results, which is expected given that the real exchange rate is very highly persistent. To avoid unnecessary complications, we eliminate these terms from our specification.

Finally, we calculate all standard errors using the delete- 1 jackknife methodology of Shao and $\mathrm{Wu}(1989)$ and Shao (1989). To compute the jackknife for a 
panel over time period $T$ for an estimator $\hat{\theta}$, we form $T-1$ delete- 1 jackknife $\hat{\theta}_{-i}$ 's by deleting one cross-section at a time. The estimated standard error of $\hat{\theta}$ is given as $\sqrt{T-1}$ times the standard deviation of the $\hat{\theta}_{-i}$ 's. The jackknife estimator, besides being nonparametric, has the added advantage of being heteroskedasticity and autocorrelation consistent. Standard errors were also computed using the delta method, and the results are comparable.

\subsection{Results}

Our first result concerns the variance decomposition of currency excess returns, shown in Table 4. For the major countries, we find that expected return shocks are considerably larger than cashflow shocks. Naturally, this is dominated by longer-term expected return shocks, which alone are $377 \%$ of cashflow shocks. By comparison, short-term expected return shocks are only about $2 \%$ of cashflow shocks. Expected return shocks become more important once we include emerging markets in the panel. For all countries together, long-term and short-term expected return shocks become $689 \%$ and $29 \%$, respectively, of cashflow shocks. Either way, expected return shocks appear to dominate at long horizons, whereas cashflow shocks dominate at short horizons. ${ }^{15}$

Our second result is an estimate of the under/over-reaction of exchange rates to cashflow shocks. Figures $2 \mathrm{a}$ and $2 \mathrm{~b}$ depict the impulse response of cumulative excess returns to a 50 basis point cashflow shock from the VAR. Both graphs show that the exchange rate appreciates immediately in response to the good cashflow news. However, the full appreciation does not occur immediately. For excess returns to peak, it requires approximately 70 additional days for the major countries and about 15 additional days for all countries. The additional return added is about 10 basis points over these periods. About half of this amount comes from a higher interest differential, since cumulated excess returns rise by more than the real exchange rate. After the follow-on increase, there is a noticeable decline in returns, particularly for all countries between 15 and 65 days. These estimates suggest that the currency underreacts initially, but that from a longer perspective, it overreacts. The longer-run evidence does not, however, appear to be statistically significant.

As expected, the return response to an increase in expected returns is negative.

\footnotetext{
${ }^{15}$ Note that this result is reversed if we truncate the lags of the VAR to be relatively shortterm, e.g., under a few weeks. In that case, variation in cashflows dominates variation in expected returns.
} 
Figure 3 shows the impulse response for both major and all our currencies. Both pictures show a strong decline in returns initially, and relatively little movement thereafter.

When we calculate the under/over reaction coefficient in equation (3.12) directly from Table 4, we find that for all countries,

$$
\beta_{\text {over }}=1-0.34+0.75=1.41
$$

The -0.34 indicates that over short horizons, the exchange rate underreacts by $34 \%$ to cashflow news. Longer-term horizons more than make up for this underreaction, however, as the currency overreacts by $75 \%$ (relative to the cashflow shock). For the major currencies only, the under- and over-reaction numbers are smaller; comparable estimates are: $\beta_{\text {over }}=1-0.04+0.26=1.22$.

Next, we explore the flow response to these shocks. Figure 4 shows the currency flow response to a cashflow shock. There are strong inflows over short horizons and then outflows at longer horizons, much in keeping with the under/overreaction results in the currency itself. By itself this is consistent with the trendchasing story. However, we can sharpen this observation by examining how flows respond to a surprise currency appreciation that involves no change in cashflows. Such a surprise appreciation requires a decline in expected return. If investors are mechanical trend-chasers, there should be inflows in such a case, even though expected returns have fallen. Figure 5 displays the flow response to this shock, a decline in short-term expected returns. It shows a strong negative relationship: when the currency appreciates due to a decline in short-term expected returns, there is a strong outflow in the short run. This is further evidence that institutional investors are exploiting the under/over-reaction pattern in currency changes. Finally, we look at flows after a currency appreciation due to a decline in long-horizon expected returns. Figure 6 shows that inflows are strong. Thus, trend-chasing occurs when a current appreciation is due to either a permanent shock to fundamentals, or to a decline in long-horizon expected returns.

Now we can turn to the estimates of the cells in Table 3. These cells allow us to compare the relative magnitudes of the price impact, anticipation, trend-chasing, and related effects. First, the price impact effect (first row, first column), shows a correlation of current flow and return surprises to be $28 \%$ for the major currencies and $9 \%$ for the full panel. This is roughly what we found from the naive regression in the previous section. Second, one line down is the simple trend-chasing effect over short horizons. It is driven by the covariance of expected cumulated flow 
innovations over 30 days with a current return shock. Note that at $29 \%$ and $16 \%$, for majors and all respectively, short-term trend chasing is somewhat larger in magnitude than the price impact estimates. The response of expected future flow to a return shock is therefore greater than the contemporaneous flow shock. Third, the next row down is our estimate of longer-term trend chasing. Here, the response to a return shock of expected flows is negative for the majors and positive for the entire cross section. Neither is statistically significant. Thus, a current appreciation has little relation on average to changes in long-term expected flows. Overall, the last row shows some weak evidence that the effect of a return shock on current and expected future flows is positive.

Next we turn to the comovement of expected returns with flows. These are in columns 2 and 3 of Table 3 . The first row of columns 2 and 3 reports, respectively, the short-term and long-term anticipation effects - the predictions for future excess returns emerging from current flow surprises. Over short flow horizons, there is positive anticipation, so that flows positively predict future returns over 30 day intervals. Over longer horizons, however, the anticipation turns negative as the transitory impacts of the exchange rate shock are worked off. This is not surprising given the overreaction effects we have identified, and given the negative long-horizon contemporaneous correlation between flows and returns from the previous section. Today's shock to inflows forecasts longer-term outflow and depreciation. Figures $7 \mathrm{a}$ and $7 \mathrm{~b}$ show the impulse response to a 1 standard deviation flow shock. There is clearly statistically significant predictable appreciation over the short run.

In the second and third rows of columns 2 and 3, we measure the comovement of expected returns and expected flows. Column 2, row 2 reports comovement between short-term expected flows and returns. These are positive and slightly statistically significant. Column 3, row 3 reports the same covariance for longerterm expected flows and returns. There is little evidence here of a linkage between cumulated innovations in long-horizon expected returns and flows.

Finally, we examine column 4 of Table 3, which shows the association between cashflow news, i.e., permanent return shocks, and flows. This shows the comovements with flows after the transitory effects of expected return variation have been removed. We see in rows 1 and 2 that both flow surprises and innovations in short-term flow forecasts are positively correlated with cashflow shocks. Innovations in long-term flow forecasts in row 3 are more mixed. The sum of these is reported in row 4, column 4 . These effects about offset one another, leading to a net result of about zero. We can interpret this cell as a kind of infinite-horizon 
correlation between flows and returns; it traces out the infinite horizon correlation from a current flow and return shock. This is related to the $k$-period-horizon correlations between flows and returns calculated in the previous section. Appendix III below derives the exact relationship between the two approaches. The results here, in any case suggest that the infinite-horizon comovement of flows and returns is essentially zero. Flows appear to have very important transitory impacts on exchange rates, but not permanent impacts. As we see below, this is not the case for fundamentals.

\subsubsection{Interest differentials with flows and returns}

The next set of questions pertains to the relationship between flows and the driving fundamentals of real exchange rates. How strongly are innovations in flows and interest differentials related? Which tends to anticipate the other? Are innovations in the present value of expected inflows and interest differentials highly correlated? To address these questions, we perform a similar decomposition to Table 3, only for returns and interest differentials instead of returns and flows.

Table 5 summarizes the interest-differentials / returns interaction. There are several striking features here as well. First, return shocks (column 1) are positively correlated with innovations in expected future interest differentials at short horizons (row 2) and long horizons (statistically insignificant) (row 3). Currency appreciations therefore positively anticipate future increases in real interest rates, especially over short horizons. Second, short-term expected returns (column 2) are positively correlated with expected future interest differentials. So it appears that innovations in real interest differentials have some positive forecasting power for short-term currency movements. Third, evidence of a link between innovations to long-term expected returns and interest differentials (column 3 ) is tenuous. There is some statistically insignificant evidence that innovations in long-term expected returns are negatively related to innovations in distant expected future interest differentials. In spite of this, cashflow shocks (column 4) remain positively correlated with current, short-term expected, and long-term expected innovations in interest differentials (rows 1-3).

Perhaps the most important result in this table is again in the last cell (row 4, column 4). It shows a kind of infinite-horizon correlation between interest differentials and returns from a current shock. Interestingly, this result is statistically positive for interest differentials in Table 5, though it was zero for flows

in Table 3. Shocks to interest differentials and permanent shocks to currencies 
are strongly positively correlated over the long run. Even though our measure of fundamentals may contain considerable error, it nevertheless behaves like a measure of fundamentals should. Notice that the analogous covariance between current observed currency shocks and the total interest differential shock (row 4, column 1) is positive, but not statistically significant. The relationship between long-horizon changes in interest differentials and currencies becomes apparent only when looking at the permanent component of returns. It is interesting to note that essentially all of these long-horizon features of Table 5 hold in a VAR which excludes flows altogether. Thus, there is nothing substantive about the relationship between interest differentials and returns that is driven by flows. Table 6 reports the same set of covariances derived from a three-equation VAR which eliminates flows.

Table 7 summarizes the interaction between interest differentials and flows. Here there are really just two points to make. First, current flow shocks do appear to predict future changes in interest differentials, at least at short horizons (row 2, column 1). Institutional investors and the exchange rate both seem to anticipate these short-run changes in interest differentials. The second result is that none of the other cells are statistically significant, including the infinite horizon covariance in the last cell (row 4, column 4). There is no detectable correlation at infinite horizons between cumulated innovations in flows and interest differentials. Overall the table argues that the relationship between flows and interest differentials is very weak. If flows represent demand shocks and interest differentials represent fundamentals, a not-so-bad approximation is that these two are unrelated. 


\section{Conclusions}

Our goal in this paper has been to understand how the currency flows of institutional investors interact with excess currency returns. We have proceeded using both naive and more sophisticated techniques, but both give essentially similar answers. Returns and flows are highly contemporaneously correlated at daily horizons, and even more highly correlated at monthly horizons. The reason that correlations increase with horizon is that current day returns are positively correlated with future flows, and, to a lesser extent, current day flows are positively correlated with future excess returns. At horizons longer than about 40 trading days, these effects begin to reverse: current flows' predictions for future excess returns eventually turn from positive to negative as horizon increases. And similarly, current returns' predictions for flows are initially positive and increasing, and then are decreasing as horizon grows.

We decompose currency returns into components attributable to cashflow news and expected return news, essentially breaking excess return shocks into permanent and temporary components, respectively. We find that the latter component is the dominant source of currency fluctuations. We also find that exchange rate surprises generally exceed their permanent component initially and exceed them by even more over the following 30 trading days. Thus, currency returns exhibit underreaction at short horizons and overreaction at long horizons, a pattern that is familiar from equity returns.

We also find that investor flows respond positively to appreciations that are generated by cashflow news and to those generated by declines in long-horizon expected returns. However, appreciations generated by declines in short-horizon expected returns result in outflows. This suggests that investors strongly distinguish between permanent and temporary appreciations in their behavior. Institutional investors are clearly not naive trend-chasers.

In addition, we inspect the behavior of fundamentals (measured by real exchange rates and real interest differentials) in relation to both returns and flows. Interestingly, we find a strong positive correlation between the permanent component of excess returns and fundamentals, and almost a zero correlation between total excess returns and fundamentals. This is consistent with Meese and Rogoff (1983), but also consistent with longer-horizon studies, such as Mark (1995), that detect a positive relationship between fundamentals and exchange rates. Our analysis makes it clear that the infinite horizon return / fundamental correlation is easily detectable, even in relatively short time-series samples. 
Finally the relationship between flows and fundamentals is noticeably weaker. There is some evidence that over short periods of time, inflows anticipate future improvements in fundamentals. Besides that, however, there is essentially no evidence that flows and fundamentals move together even at long leads and lags.

Putting these pieces together, it is clear that we find no support for a strong flow-centric view. Flows don't have much to say (except over very short horizons) about future fundamentals. Fundamentals have plenty to say about returns (especially over long horizons). And permanent exchange-rate returns are essentially unrelated to permanent measures of flow. So the strong flow-centric view, which has flows generating permanent exchange rate impacts, potentially even proxying for cumulated innovations in future fundamentals, is rejected. Flows seem to help understand transitory excess returns, e.g., short-run underreaction and long-run overreaction, not permanent excess returns. As a result, the evidence seems most to fit the weak version of the flow-centric view. We also find support for the fundamentals-only view at long horizons. There, fundamentals win out in explaining currencies, and flows have little impact. In sum, if flows are to be called the 'proximate' cause for currency movements, it is only for those movements that are highly transitory. 


\section{Appendix}

\section{Appendix I}

\section{Valuing forward transactions}

All transactions for a given trade date report future value amounts bought and sold. To aggregate the trades, we must compute the present value of these amounts. Because we do not have the prevailing spot rate at the exact time of the trade, we discount both sides (currency bought and currency sold) of the forward transaction by the local-currency interest rate corresponding to the time between trade and settlement dates.

In doing this, we use the following formula, utilizing conventions in the foreign exchange market for pricing forward contracts:

$$
P V_{t}^{c}=\delta_{t}^{c} A_{t, m}^{c}, \text { where } \delta=\left(\left(1+i_{m, t}^{c}\right)^{\left\lfloor m / T^{c}\right\rfloor}\left(1+\left(i_{m, t}^{c}\right)\left(m-\left\lfloor m / T^{c}\right\rfloor\right)\right)^{-1}\right.
$$

The interest rate for currency $c$ for maturity $m$ is given by $i_{m, t}^{c}$. The discount factor, $\delta_{t}^{c}$, is applied to the amount transacted forward, $A_{t, m}^{c}$, in currency $c$ at time $t$, in local currency, settling at $t+m . A_{t, m}^{c}$ can be either positive (currency bought) or negative (currency sold). Note that this convention implies that the interest rate is compounded over complete calendar year intervals. Simple interest accrues over any remaining interval under a full year $(\lfloor a / b\rfloor$ is the floor operator, which rounds the variable within it to the nearest integer towards negative infinity). $T^{c}$ here represents the daycount basis for currency $c$. This is 360 for all countries except Hong Kong, Malaysia, Singapore, South Africa, Thailand, and the UK.

If local currency interest rates are not available for one side of the transaction, we present value the other side. We then convert at the spot exchange rate to estimate the present value. For transactions that do not match the maturities of available interest rates, we linearly interpolate or extrapolate using available rates.

We also filter out transactions that are likely to have important data entry or interest-rate-measurement errors. Specifically, we remove a transaction if the difference between the PV amount bought and sold is greater than $\$ 1,000,000$ or if the percentage difference is greater than $30 \%$. We exclude transactions in the sparsely-traced currencies of Brazil, Kenya, Luxembourg, Peru, Russia, Turkey and Zimbabwe. After applying these filters, we are left with a total of 6,402,392 transactions of all maturities. 
At this point we can aggregate the transaction values by currency. We then normalize the dollar value of flow by own-country daily dollar standard-deviation of flow. We also experimented with normalizing the flow data by the money supply of the respective country, which yields essentially similar results. The monthly reporting of money supply values introduces additional time series complications, and thus, in the empirical work, we measure flows in units of own-country standard deviations.

Interest rate, exchange rate, and inflation data

To construct yield curves for present valuation, we obtain daily interbank interest rates for various horizons from one week to one year from Datastream. When these are unavailable, we use corporate and/or deposit rates. If these too are unavailable, we use country treasury bill rates. When maturities are missing, we linearly interpolate or extrapolate. For longer-term rates, we use swap or sovereign bond rates at various maturities from 1 to 25 years. Swap rates are from Datastream for the 'major' currencies of Australia, Canada, Germany, Japan, the UK and US.

To construct excess returns and interest differentials we employ spot and one-month forward exchange rates. These are 11:00 a.m. EST rates from WMR/Reuters as far back as possible. Prior to that we use Datastream or Barclays Bank data.

Inflation is constructed from differences in monthly log Consumer Price Index (CPIs) from IFS. There were problems with seasonality in Poland's inflation data, and in some data points 12-month moving averages were used to smooth them out. We construct the daily inflation series from the monthly series, by assuming that inflation occurs smoothly within the month. We also lag this series by half a month, in order to ensure inflation is in the current information set.

\section{Appendix II}

\section{Monte Carlo design}

The Monte Carlo is conducted by first drawing a multivariate normal flowreturn pair for the stacked panel at the daily frequency, using a mean and covariance matrix derived from the 'true' stacked flow-stacked return pair for that country. In our specifications below, we use both the moments of the panel at the daily return horizon, and the implied daily moments derived from the moments of the panel at the monthly return horizon. We also do a second set of draws imposing zero contemporaneous correlation between flows and returns at the daily frequency. In other words, we use 


$$
\begin{aligned}
& \left(\begin{array}{c}
\omega_{f} \\
\omega_{r}
\end{array}\right) \sim N\left(\left(\begin{array}{c}
\mu_{f} \\
\mu_{r}
\end{array}\right),\left(\begin{array}{cc}
\sigma_{f}^{2} & \sigma_{f r} \\
\sigma_{f r} & \sigma_{r}^{2}
\end{array}\right)\right) \\
& \left(\begin{array}{c}
\omega_{f}^{z} \\
\omega_{r}^{z}
\end{array}\right) \sim N\left(\left(\begin{array}{c}
\mu_{f} \\
\mu_{r}
\end{array}\right),\left(\begin{array}{cc}
\sigma_{f}^{2} & 0 \\
0 & \sigma_{r}^{2}
\end{array}\right)\right)
\end{aligned}
$$

as our daily draws, where $\omega_{f}$ and $\omega_{r}$ are draws computed using the actual daily (or monthly) covariances of flows and returns, and $\omega_{f}^{z}$ and $\omega_{r}^{z}$ impose zero contemporaneous correlation between flows and returns at the daily (or monthly) frequency.

Each daily draw's $\beta$ and $\rho$ statistics are computed, and then adjacent observations in each country are summed up to the next return horizon in a nonoverlapping fashion. The panel is then re-stacked at the new, lower frequency, and the simulated sample statistics at the new horizon are then computed. This process continues on up until the $T$ day return horizon, which is a cross-sectional regression $N \times 1$. We then sort all Monte Carlo estimated panel $\beta$ and $\rho$ statistics across each return horizon, and report the point-wise confidence intervals from the experiment, as standard error bounds around the estimated $\beta$ and $\rho$ statistics from our original sample. We also report the bias of the 'true' $\beta$ and $\rho$ statistics away from the 50th percentile Monte Carlo draw, again sorted point-wise.

Notice that this procedure is equivalent to drawing a different set of daily draws to compute point-wise confidence intervals for the panel R-squared at each return horizon. Since these draws are i.i.d., the same set of draws will suffice for every return horizon. We do 10,000 trials for each simulation. Note also, as mentioned above, that since we construct confidence intervals using draws of flows and returns from a multivariate normal distribution, with zero autocorrelation imposed in our drawn flows and returns, the point-wise confidence intervals we obtain using nonoverlapping computations will apply equally well to sample statistics computed for our data using overlapping return windows.

In order to represent the change of horizon in a convenient and readily comprehensible form: let $T$ be the number of days in the entire sample $(1,855)$, and $N$ be the number of countries (19). We compute R-squared statistics at return horizons $H=\{1, \ldots, T\}$.

Hence, in the panel, the Monte Carlo regressions are run with $(N T / H)$ numbers of observations as $H$ changes. Notice that when $H=T$, the panel regression 
becomes a cross-sectional regression $N \times 1$, with each observation of flows representing the total net inflow over the entire sample period of 1,855 days, and each observation of returns representing the total excess currency return over the entire sample period of 1,855 days for the respective country. When $H=1$, we run the entire panel regression $N \times T$.

\section{Appendix III}

\section{Connecting the VAR with the naive approach}

Using the VAR, it is possible to derive the $R^{2}$ statistics from the naïve approach. In addition, we can use the VAR to be more precise about low-frequency co-movements. We can approximate the $K$-period return and flow, respectively, as

$$
\begin{aligned}
& r_{t, j}(K)=\sum_{k=1}^{K} r_{t+1-k, j} \approx \sum_{k=1}^{K} e 1^{\prime} \Psi(k) u_{t+1-k} \\
& F_{t, j}(K)=\sum_{k=1}^{K} f_{t+1-k, j} \approx \sum_{k=1}^{K} e 2^{\prime} \Psi(k) u_{t+1-k}
\end{aligned}
$$

The approximation occurs because we assume that before the start of the sample, we have $u_{t}=0$, for all $t \leq 0$. As a result, the conditional expectation of future returns and flows is built up entirely from innovations that occur during the sample period.

With these assumptions, and noting that the $u$ 's are uncorrelated at all leads and lags, we can write the OLS slope coefficient from a regression of $f(K)$ on $F(K)$ as:

$$
\beta(K)=\frac{\sum_{k=1}^{K} e 1^{\prime} \Psi(k) \Sigma \Psi(k)^{\prime} e 2}{\sum_{k=1}^{K} e 2^{\prime} \Psi(k) \Sigma \Psi(k)^{\prime} e 2},
$$

and correspondingly, the $\rho$ as

$$
\rho(K)=\frac{\sum_{k=1}^{K} e 1^{\prime} \Psi(k) \Sigma \Psi(k)^{\prime} e 2}{\left(\sum_{k=1}^{K} e 1^{\prime} \Psi(k) \Sigma \Psi(k)^{\prime} e 1\right)^{1 / 2}\left(\sum_{k=1}^{K} e 2^{\prime} \Psi(k) \Sigma \Psi(k)^{\prime} e 2\right)^{1 / 2}}
$$

These expressions remind us that multiperiod returns and flows combine news from various periods. In a 3-period return, for example, first-period news and 
its impact on period-2 and period-3 expected outcomes is combined with later news, including, for example, period-3 news, where any impact on later-period expectations is expressed only in subsequent 3-period observations. To isolate the multiperiod comovement attributable to current-period news, it is more appropriate to use the VAR impulse response. The total $K$-period comovement of returns and flows from current-period news is described by

$$
\begin{aligned}
& \beta(K)=\frac{e 1^{\prime} \Psi(K) \Sigma \Psi(K)^{\prime} e 2}{e 2^{\prime} \Psi(K) \Sigma \Psi(K)^{\prime} e 2} \\
& \rho(K)=\frac{\left(e 1^{\prime} \Psi(n) \Sigma \Psi(n)^{\prime} e 2\right)}{\left(e 1^{\prime} \Psi(n) \Sigma \Psi(n)^{\prime} e 1\right)^{1 / 2}\left(e 2^{\prime} \Psi(n) \Sigma \Psi(n)^{\prime} e 2\right)^{1 / 2}},
\end{aligned}
$$

where $\beta$ is the coefficient from a regression of the $n$-period innovation in return on the $n$-period innovation in flow. 


\section{References}

[1] Barberis, N. and A. Shleifer, 2002, "Style investing," forthcoming, Journal of Financial Economics.

[2] Beveridge, S. and C. R. Nelson,1981, "A new approach to the decomposition of economic time series into permanent and transitory components with particular attention to the measurement of the 'Business Cycle'," Journal of Monetary Economics, 7, 151-174.

[3] Brennan, M. and H. Cao, 1997, "International portfolio investment flows," Journal of Finance, 52, 1851-1880.

[4] Cai, J., Cheung, Y., Lee, R.S.K., and M. Melvin, 2001, “"Once-in-ageneration" yen volatility in 1998: fundamentals, intervention, and order flow," Journal of International Money and Finance, 20, 3, 327-347.

[5] Campbell, J., 1991, "A variance decomposition for stock returns," Economic Journal, 101, 157-179.

[6] Campbell, J. and R. Clarida 1987, "The dollar and real interest rates," Carnegie-Rochester Conference Series on Public Policy, 27, 103-139.

[7] Campbell, J. and R. Shiller, 1988, "The dividend-price ratio and expectations of future dividends and discount factors," Review of Financial Studies, 1, 195-227.

[8] Cheung, Y. and M. D. Chinn, 2000, "Currency traders and exchange rate dynamics: a survey of the U.S. market," unpublished working paper.

[9] Choe, H., B. C. Kho, and R. M. Stulz, 2001, "Do domestic investors have more valuable information about individual stocks than foreign investors?," NBER working paper no. 8073.

[10] Clarida, R. and J. Gali, 1994, "Sources of real exchange rate fluctuations: how important are nominal shocks?," Carnegie-Rochester Conference Series on Public Policy, 41, 1-56.

[11] Cohen, R., P. Gompers, and T. Vuolteenaho, 2001, "Who underreacts to cashflow news? Evidence from trading between individuals and institutions," manuscript, Harvard University. 
[12] Coval, J. D., and T. J. Moskowitz, 2001, "The geography of investment: informed trading and asset prices." Journal of Political Economy 109, 4, 811-841.

[13] Daniel, K., Hirshleifer, D. and A. Subrahmanyam, 1998, "Investor psychology and security market under- and over-reactions," Journal of Finance, 53(5),1839-1886.

[14] DeBondt, W.F.M., R. H. Thaler, 1985, "Does The Stock Market Overreact?" Journal of Finance,40, 793-80.

[15] Engel, C., 2001, "Notes on Cointegration of Real Interest Rates and Real Exchange Rates," research website, http://www.ssc. wisc.edu/ cengel/RealCointNotes.pdf.

[16] Evans, M.D.D. and R. Lyons, 2002, "Order flow and exchange rate dynamics," Journal of Political Economy, February 2002, 170-180.

[17] Evans, M.D.D. and R. Lyons, 2001 "Why order flow explains exchange rates," Unpublished Working Paper

[18] Froot, K., P. O'Connell, and M. Seasholes, 2001, "The portfolio flows of international investors," Journal of Financial Economics, 59, 151-193.

[19] Froot, K. and T. Ramadorai, "The information content of international portfolio flows," NBER working paper no. 8472.

[20] Grinblatt, M., Titman, S., R. Wermers, 1995, "Momentum investment strategies, portfolio performance, and herding: a study of mutual fund behavior," American Economic Review, 85, 1088-1105.

[21] Hasbrouck, J., 1991, "Measuring the information content of stock trades," Journal of Finance 46, 179-207.

[22] Hong, H. and J. Stein, 1999, "A unified theory of underreaction, momentum trading and overreaction in asset markets" Journal of Finance, 54, 2143-2184.

[23] Jegadeesh, N. and S. Titman, 1993, "Returns to buying winners and selling losers: implications for stock market efficiency," Journal of Finance, 48, 6591. 
[24] Jegadeesh, N. and S. Titman, 2001, "Profitability of momentum strategies: an evaluation of alternative explanations," Journal of Finance, 560, 699-720.

[25] Mark, N., 1995, "Exchange rates and fundamentals: evidence on long-horizon predictability," American Economic Review, 85, 201-218.

[26] Meese, R., and K. Rogoff, 1983, "Empirical exchange rate models of the seventies," Journal of International Economics, 14, 3-24.

[27] Payne, R., 2000, "Informed trade in spot foreign exchange markets: an empirical investigation," mimeo, Financial Markets Group, LSE.

[28] Rime, D., 2000, "U.S. exchange rates and currency flows," unpublished working paper.

[29] Rouwenhorst, G. 1998, "International momentum strategies," Journal of Finance, 53, 267-284.

[30] Seasholes, M., 2001, "Smart foreign traders in emerging markets," unpublished working paper.

[31] Shao, J., 1989, "The efficiency and consistency of approximations to the jackknife variance estimators", Journal of the American Statistical Association, 84, 114-119.

[32] Shao, J. and C. F. J. Wu, 1989 "A general theory for jackknife variance estimation," Annals of Statistics, 17, 1176-1197.

[33] Griffin, J.M., Nardari, F., and R.M. Stulz, 2002, "Daily cross-border equity flows: pushed or pulled?" Dice Center working paper 2002-6.

[34] Thaler, R. and W. F. M. DeBondt, 1985, "Does the stock market overreact?" Journal of Finance, 40, 793-805.

[35] Vuolteenaho, T., 2002, "What drives firm-level stock returns?," Journal of Finance, 57, 1, 233-264.

[36] Wei, S.J. and J. Kim, 1997, "The big players in the foreign exchange market: do they trade on information or noise?," NBER working paper no. 6256. 


\section{Table 1}

\section{Descriptive Statistics: Foreign Exchange Flows}

The sample period is from January 1, 1994 to February 9, 2001. The flow data are from State Street Corporation (SSC). The first two columns report the mean of daily absolute aggregate flows $(a)$, and standard deviation of daily net flows in hundreds of millions of US\$. The third column reports the daily partial autocorrelation of aggregate flows. The fourth column reports the second partial autocorrelation under the restriction that days $2-5$ have the same coefficient. The fifth reports the same for days 6-10. Columns six, seven and eight report the partial autocorrelations for currency excess returns, with the same coefficient restrictions imposed. Column nine reports the daily contemporaneous correlation between flows and currency excess returns.

\begin{tabular}{|c|c|c|c|c|c|c|c|c|c|}
\hline & $\hat{\mu}\left(\left|f^{a}\right|\right)$ & $\hat{\sigma}\left(f^{a}\right)$ & $\hat{\rho}_{1}\left(f^{a}\right)$ & $\hat{\rho}_{2}\left(f^{a}\right)$ & $\hat{\rho}_{3}\left(f^{a}\right)$ & $\hat{\rho}_{1}(r)$ & $\hat{\rho}_{2}(r)$ & $\hat{\rho}_{3}(r)$ & $\rho\left(f^{a}, r\right)$ \\
\hline Majors & US\$100M & US\$100M & & & & & & & \\
\hline U.S. & 2.730 & 3.753 & 0.212 & 0.040 & 0.001 & & & & \\
\hline Euroland & 1.636 & 2.242 & 0.170 & 0.039 & 0.009 & 0.012 & 0.004 & -0.001 & 0.330 \\
\hline Japan & 1.418 & 2.102 & 0.177 & 0.055 & 0.001 & 0.050 & -0.006 & 0.010 & 0.310 \\
\hline U.K. & 0.860 & 1.229 & 0.222 & 0.009 & 0.006 & 0.038 & -0.001 & -0.011 & 0.377 \\
\hline Switzerland & 0.674 & 1.023 & 0.185 & 0.034 & 0.002 & 0.096 & -0.036 & 0.001 & 0.257 \\
\hline Canada & 0.537 & 0.909 & 0.132 & 0.055 & 0.004 & 0.055 & -0.021 & -0.004 & 0.148 \\
\hline Australia & 0.466 & 0.669 & 0.094 & 0.026 & 0.017 & 0.007 & -0.010 & -0.000 & 0.269 \\
\hline \multicolumn{10}{|l|}{ Others } \\
\hline Sweden & 0.239 & 0.383 & 0.122 & 0.010 & 0.006 & 0.058 & -0.018 & -0.018 & 0.116 \\
\hline New Zealand & 0.141 & 0.303 & 0.025 & 0.018 & 0.005 & -0.064 & -0.036 & 0.004 & 0.073 \\
\hline Korea & 0.098 & 0.206 & 0.219 & 0.049 & 0.036 & 0.123 & -0.092 & 0.084 & 0.024 \\
\hline Singapore & 0.088 & 0.188 & 0.034 & 0.038 & 0.016 & -0.020 & 0.000 & -0.027 & 0.050 \\
\hline Norway & 0.067 & 0.151 & 0.090 & 0.006 & 0.010 & 0.020 & -0.025 & -0.014 & 0.123 \\
\hline Mexico & 0.051 & 0.106 & 0.134 & 0.074 & -0.011 & -0.095 & 0.016 & 0.014 & 0.054 \\
\hline South Africa & 0.048 & 0.089 & 0.148 & 0.029 & 0.040 & 0.042 & -0.002 & -0.001 & 0.088 \\
\hline Taiwan & 0.046 & 0.106 & 0.033 & 0.059 & 0.047 & 0.160 & -0.004 & 0.008 & 0.060 \\
\hline Thailand & 0.036 & 0.080 & 0.110 & 0.068 & 0.000 & 0.163 & -0.013 & 0.009 & 0.006 \\
\hline India & 0.027 & 0.078 & 0.005 & 0.085 & 0.030 & 0.115 & 0.023 & -0.004 & 0.026 \\
\hline Indonesia & 0.026 & 0.043 & 0.199 & 0.059 & 0.010 & 0.115 & -0.003 & 0.013 & 0.037 \\
\hline Poland & 0.021 & 0.072 & 0.066 & -0.016 & -0.016 & -0.036 & -0.019 & -0.003 & 0.117 \\
\hline Philippines & 0.021 & 0.034 & 0.125 & 0.072 & 0.042 & 0.060 & -0.056 & -0.019 & 0.100 \\
\hline
\end{tabular}


Table 2

\section{Country Univariate Regressions: Aggregate Flows and Excess Returns}

This table presents estimates of equation (1): $R_{t}(h)=\hat{\alpha}+\hat{\beta}^{h} F_{t}(h)+\hat{\varepsilon}_{t}$ for return horizons $h=1,5,20,60,120,240$ and 400 days. Flows are summed in an overlapping fashion at each successive return horizon, and matched against currency excess returns for the specified period. Flows are in US $\$ 100$ millions, returns in basis points. The columns are arranged in ascending order of return horizon, reporting $\hat{\beta}^{h}$ (with standard errors below in italics) and $\hat{\rho}^{h}$, the contemporaneous correlation coefficient.

\begin{tabular}{|c|c|c|c|c|c|c|c|c|c|c|c|c|c|c|}
\hline & $\hat{\beta}^{1}$ & $\hat{\rho}^{1}$ & $\hat{\beta}^{5}$ & $\hat{\rho}^{5}$ & $\hat{\beta}^{20}$ & $\hat{\rho}^{20}$ & $\hat{\beta}^{60}$ & $\hat{\rho}^{60}$ & $\hat{\beta}^{120}$ & $\hat{\rho}^{120}$ & $\hat{\beta}^{240}$ & $\hat{\rho}^{240}$ & $\hat{\beta}^{400}$ & $\hat{\rho}^{400}$ \\
\hline \multicolumn{15}{|l|}{ Majors } \\
\hline \multirow[t]{2}{*}{\begin{tabular}{|l} 
Euroland \\
\end{tabular}} & 8.95 & 0.33 & 10.76 & 0.48 & 9.91 & 0.53 & 7.15 & 0.44 & 4.94 & 0.29 & 1.20 & 0.05 & -1.37 & -0.07 \\
\hline & 0.59 & & 0.45 & & 0.37 & & 0.34 & & 0.39 & & 0.57 & & 0.55 & \\
\hline \multirow[t]{2}{*}{ Japan } & 11.20 & 0.31 & 13.61 & 0.47 & 14.10 & 0.56 & 16.02 & 0.55 & 16.01 & 0.54 & 10.38 & 0.39 & 8.47 & 0.33 \\
\hline & 0.80 & & 0.59 & & 0.49 & & 0.57 & & 0.60 & & 0.60 & & 0.64 & \\
\hline \multirow[t]{2}{*}{ U.K. } & 14.09 & 0.38 & 14.74 & 0.48 & 13.92 & 0.50 & 8.52 & 0.37 & 5.10 & 0.22 & 5.95 & 0.27 & 7.51 & 0.38 \\
\hline & 0.81 & & 0.63 & & 0.56 & & 0.50 & & 0.53 & & 0.53 & & 0.48 & \\
\hline \multirow[t]{2}{*}{ Switzerland } & 5.91 & 0.26 & 7.37 & 0.39 & 5.91 & 0.37 & 4.89 & 0.32 & 7.67 & 0.42 & 7.76 & 0.44 & 1.91 & 0.13 \\
\hline & 0.52 & & 0.41 & & 0.34 & & 0.34 & & 0.40 & & 0.39 & & 0.38 & \\
\hline \multirow[t]{2}{*}{ Canada } & 5.01 & 0.15 & 5.09 & 0.18 & 5.30 & 0.24 & 4.56 & 0.26 & 3.20 & 0.23 & 1.59 & 0.14 & -0.26 & -0.02 \\
\hline & 0.78 & & 0.66 & & 0.50 & & 0.40 & & 0.33 & & 0.28 & & 0.32 & \\
\hline \multirow[t]{2}{*}{ Australia } & 23.74 & 0.27 & 27.84 & 0.36 & 26.08 & 0.40 & 24.37 & 0.39 & 25.55 & 0.36 & 46.23 & 0.42 & 21.41 & 0.17 \\
\hline & 1.98 & & 1.66 & & 1.38 & & 1.35 & & 1.57 & & 2.47 & & 3.31 & \\
\hline \multicolumn{15}{|l|}{ Others } \\
\hline \multirow[t]{2}{*}{\begin{tabular}{|l|} 
Sweden \\
\end{tabular}} & 12.21 & 0.12 & 22.52 & 0.24 & 25.59 & 0.31 & 25.99 & 0.39 & 21.46 & 0.35 & 8.25 & 0.14 & 3.47 & 0.05 \\
\hline & 2.44 & & 2.16 & & 1.81 & & 1.43 & & 1.39 & & 1.47 & & 1.74 & \\
\hline \multirow[t]{2}{*}{ New Zealand } & 10.27 & 0.07 & 13.92 & 0.11 & 14.12 & 0.13 & -16.94 & -0.15 & -40.89 & -0.38 & -57.28 & -0.49 & -73.91 & -0.57 \\
\hline & 3.28 & & 2.81 & & 2.42 & & 2.56 & & 2.37 & & 2.53 & & 2.78 & \\
\hline \multirow[t]{2}{*}{ Korea } & 13.10 & 0.02 & 23.93 & 0.06 & 36.09 & 0.12 & 53.48 & 0.19 & 38.45 & 0.16 & 37.39 & 0.16 & 59.21 & 0.25 \\
\hline & 12.89 & & 9.65 & & 7.11 & & 6.71 & & 5.81 & & 5.78 & & 6.01 & \\
\hline \multirow[t]{2}{*}{ Singapore } & 9.12 & 0.05 & 18.22 & 0.12 & 34.33 & 0.27 & 25.18 & 0.23 & 4.18 & 0.05 & 2.24 & 0.03 & 23.12 & 0.25 \\
\hline & 4.22 & & 3.61 & & 2.85 & & 2.53 & & 2.17 & & 2.10 & & 2.36 & \\
\hline \multirow[t]{2}{*}{ Norway } & 25.67 & 0.12 & 27.54 & 0.15 & 9.71 & 0.06 & 18.15 & 0.13 & 1.22 & 0.01 & -23.09 & -0.23 & -25.82 & -0.26 \\
\hline & 4.81 & & 4.23 & & 3.66 & & 3.18 & & 2.65 & & 2.38 & & 2.48 & \\
\hline \multirow[t]{2}{*}{ Mexico } & 64.09 & 0.05 & 177.09 & 0.19 & 307.45 & 0.38 & 348.22 & 0.42 & 205.25 & 0.26 & 48.88 & 0.07 & -44.81 & -0.08 \\
\hline & 27.62 & & 21.01 & & 17.65 & & 17.88 & & 18.23 & & 16.61 & & 14.73 & \\
\hline \multirow[t]{2}{*}{ South Africa } & 58.05 & 0.09 & 53.05 & 0.10 & 88.82 & 0.21 & 121.21 & 0.33 & 51.60 & 0.15 & 71.67 & 0.20 & 24.83 & 0.11 \\
\hline & 15.28 & & 12.23 & & 9.79 & & 8.27 & & 7.99 & & 8.52 & & 5.99 & \\
\hline \multirow[t]{2}{*}{ Taiwan } & 16.63 & 0.06 & 43.47 & 0.17 & 54.14 & 0.27 & 65.05 & 0.39 & 55.83 & 0.41 & 66.89 & 0.51 & 81.52 & 0.71 \\
\hline & 6.41 & & 6.02 & & 4.45 & & 3.61 & & 2.99 & & 2.79 & & 2.12 & \\
\hline \multirow[t]{2}{*}{ Thailand } & 5.56 & 0.01 & 23.21 & 0.03 & -30.77 & -0.04 & -51.80 & -0.06 & -58.27 & -0.07 & 34.74 & 0.04 & 328.53 & 0.36 \\
\hline & 22.30 & & 20.01 & & 18.67 & & 19.48 & & 18.77 & & 19.74 & & 22.63 & \\
\hline \multirow[t]{2}{*}{ India } & 8.93 & 0.03 & 15.72 & 0.05 & 17.29 & 0.07 & 10.37 & 0.05 & 8.42 & 0.04 & 21.63 & 0.12 & 56.99 & 0.32 \\
\hline & 8.12 & & 7.61 & & 6.00 & & 5.11 & & 4.99 & & 4.32 & & 4.41 & \\
\hline \multirow[t]{2}{*}{ Indonesia } & 188.07 & 0.04 & 292.23 & 0.07 & 276.96 & 0.08 & 297.47 & 0.11 & 77.73 & 0.03 & 78.48 & 0.04 & -29.07 & -0.02 \\
\hline & 117.64 & & 95.66 & & 76.24 & & 66.32 & & 54.60 & & 49.51 & & 42.47 & \\
\hline \multirow[t]{2}{*}{ Poland } & 76.54 & 0.12 & 140.37 & 0.23 & 180.35 & 0.29 & 145.81 & 0.24 & -31.18 & -0.06 & -210.14 & -0.29 & -130.71 & -0.21 \\
\hline & 15.11 & & 13.76 & & 13.65 & & 14.00 & & 12.09 & & 17.31 & & 15.69 & \\
\hline \multirow[t]{2}{*}{ Philippines } & 222.27 & 0.10 & 174.40 & 0.11 & 138.31 & 0.14 & 94.27 & 0.13 & 51.28 & 0.09 & 16.78 & 0.04 & 8.57 & 0.03 \\
\hline & 51.29 & & 37.98 & & 23.15 & & 17.40 & & 14.41 & & 11.03 & & 8.80 & \\
\hline
\end{tabular}


Table 3: Relationships Between Flows and Returns

Table 3 summarizes the covariances between Flows and Returns using the cashflow and expected return decomposition obtained from our VAR estimates. We present interpretations of the various elements of the relationship matrix, followed by the estimates themselves. To scale the covariances, we divide each measure

by $\left(e 1^{\prime} \Sigma e l e 2^{\prime} \Sigma e 2\right)^{1 / 2}$, the product of the innovation standard deviations. Standard errors are below coefficients in italics.

\begin{tabular}{|c|c|c|c|c|c|c|c|c|}
\hline \multirow{2}{*}{$\begin{array}{l}\text { Excess Returns } \\
\rightarrow \\
\text { Flows } \downarrow\end{array}$} & \multicolumn{2}{|c|}{$\begin{array}{l}\text { 1.Excess Return } \\
\qquad e 1^{\prime} u\end{array}$} & \multicolumn{2}{|c|}{$\begin{array}{l}\text { 2.Expected ST Return } \\
\text { Innovation } \\
e 1^{\prime} \Phi(k) u\end{array}$} & \multicolumn{2}{|c|}{$\begin{array}{c}\text { 3.Expected LT Return } \\
\text { Innovation } \\
e 1^{\prime}(\Phi-\Phi(k)) u\end{array}$} & \multicolumn{2}{|c|}{$\begin{array}{c}\text { 4.Cash Flow Innovation } \\
\text { (sum of columns 1-3) } \\
e 1^{\prime} \Psi u\end{array}$} \\
\hline & Majors & All & Majors & All & Majors & All & Major & All \\
\hline $\begin{array}{l}\text { 1. Unexpected Flow } \\
e 2^{\prime} u\end{array}$ & \multicolumn{2}{|c|}{$\begin{array}{l}\text { Price Impact } \\
\qquad e 1^{\prime} \Sigma e 2\end{array}$} & \multicolumn{2}{|c|}{$\begin{array}{l}\text { ST Anticipation } \\
e 1^{\prime} \Phi(k) \Sigma e 2\end{array}$} & \multicolumn{2}{|c|}{$\begin{array}{c}\text { LT Anticipation } \\
e 1^{\prime}(\Phi-\Phi(k)) \Sigma e 2\end{array}$} & \multicolumn{2}{|c|}{$\begin{array}{l}\text { Total Price Impact } \\
\qquad e 1^{\prime} \Psi \Sigma e 2\end{array}$} \\
\hline $\begin{array}{l}\text { 2. Expected ST Flow } \\
\text { Innovation } \\
e 2^{\prime} \Phi(k) u\end{array}$ & \multicolumn{2}{|c|}{$\begin{array}{l}\text { ST Trend Chasing } \\
e 1^{\prime} \Sigma \Phi(k)^{\prime} e 2\end{array}$} & \multicolumn{2}{|c|}{$\begin{array}{l}\text { ST Expectational Comovement } \\
\qquad e 1^{\prime} \Phi(k) \Sigma \Phi(k)^{\prime} e 2\end{array}$} & \multicolumn{2}{|c|}{$\begin{array}{l}\text { Expectational Comovement } \\
e 1^{\prime}(\Phi-\Phi(k)) \Sigma \Phi(k)^{\prime} e 2\end{array}$} & \multicolumn{2}{|c|}{$\begin{array}{c}\text { ST Cash Flow Chasing } \\
\qquad 1^{\prime} \Psi \Sigma \Phi(k)^{\prime} e 2\end{array}$} \\
\hline \multirow{2}{*}{$\begin{array}{l}\text { 3. Expected LT Flow } \\
\text { Innovation } \\
e 2^{\prime}(\Phi-\Phi(k)) u\end{array}$} & \multicolumn{2}{|c|}{$\begin{array}{c}\text { LT Trend Chasing } \\
e 1^{\prime} \Sigma(\Phi-\Phi(k))^{\prime} e 2\end{array}$} & \multicolumn{2}{|c|}{$\begin{array}{l}\text { Expectational Comovement } \\
e 1^{\prime} \Phi(k) \Sigma(\Phi-\Phi(k))^{\prime} e 2\end{array}$} & \multicolumn{2}{|c|}{$\begin{array}{c}\text { LT Expectational } \\
\text { Comovement } \\
e 1^{\prime}(\Phi-\Phi(k)) \Sigma(\Phi-\Phi(k))^{\prime} e 2\end{array}$} & \multicolumn{2}{|c|}{$\begin{array}{l}\text { LT Cash Flow Chasing } \\
e 1^{\prime} \Psi \Sigma(\Phi-\Phi(k))^{\prime} e 2\end{array}$} \\
\hline & $\begin{array}{r}-1.281 \\
1.039\end{array}$ & $\begin{array}{l}0.781 \\
0.638\end{array}$ & $\begin{array}{r}-0.020 \\
0.105\end{array}$ & $\begin{array}{l}0.168 \\
0.186\end{array}$ & $\begin{array}{l}1.175 \\
1.163\end{array}$ & $\begin{array}{r}-0.857 \\
0.687\end{array}$ & $\begin{array}{r}-0.126 \\
0.572\end{array}$ & $\begin{array}{l}0.092 \\
0.171\end{array}$ \\
\hline \multirow{2}{*}{$\begin{array}{l}\text { 4. Total Flow } \\
\text { Innovation } \\
\text { (sum of above) } \\
e 2^{\prime} \Psi u\end{array}$} & \multicolumn{2}{|c|}{$e 1^{\prime} \Sigma \Psi^{\prime} e 2$} & \multicolumn{2}{|c|}{$e 1^{\prime} \Phi(k) \Sigma \Psi^{\prime} e 2$} & \multicolumn{2}{|c|}{$e 1^{\prime}(\Phi-\Phi(k)) \Sigma \Psi^{\prime} e 2$} & \multicolumn{2}{|c|}{$e 1^{\prime} \Psi \Sigma \Psi^{\prime} e 2$} \\
\hline & $\begin{array}{r}-0.711 \\
1.038\end{array}$ & $\begin{array}{l}1.028 \\
0.650\end{array}$ & $\begin{array}{l}0.067 \\
0.097\end{array}$ & $\begin{array}{l}0.338 \\
0.214\end{array}$ & $\begin{array}{l}0.640 \\
1.043\end{array}$ & $\begin{array}{r}-1.199 \\
0.707\end{array}$ & $\begin{array}{r}-0.004 \\
0.312\end{array}$ & $\begin{array}{l}0.166 \\
0.219\end{array}$ \\
\hline
\end{tabular}




\section{Table 4: Variance Decomposition}

Table IV presents the variance decomposition using the cash flow and expected return decomposition obtained from our VAR estimates. Standard errors below coefficients in italics.

\begin{tabular}{|c|c|c|c|c|c|c|c|}
\hline & $\sigma_{f x}^{2}$ & $\sigma_{c f}^{2}$ & $\sigma_{e r}^{2}$ & $\rho_{e r, c f}$ & $\sigma_{e r(k)}^{2}$ & $\sigma_{\operatorname{er}(k+1 . . \infty)}^{2}$ & $\rho_{\operatorname{er}(k), \operatorname{er}(k+1 . . \infty)}$ \\
\hline Major & 2757.77 & 541.83 & 1977.79 & -0.12 & 9.84 & 2041.84 & -0.26 \\
Countries & 73.78 & 135.72 & 1901.06 & 0.89 & 16.54 & 1947.17 & 1.11 \\
& & & & & & & \\
All & 6330.82 & 947.43 & 4612.70 & -0.18 & 276.21 & 6523.40 & -0.81 \\
Countries & 295.36 & 248.98 & 1433.57 & 0.31 & 345.91 & 2263.84 & 0.20 \\
& & & & & & & \\
\hline
\end{tabular}


Table 5: Relationships Between Interest Differentials and Returns

Table 5 summarizes the relationships between Returns and Interest Differentials using the cash flow and expected return decomposition obtained from our VAR estimates. We present interpretations of the various elements of the relationship matrix, followed by the estimates themselves. To scale the covariances, we divide each measure by $\left(e 1^{\prime} \Sigma e l e 3^{\prime} \Sigma e 3\right)^{1 / 2}$, the product of the innovation standard deviations. Standard errors are below coefficients in italics.

\begin{tabular}{|c|c|c|c|c|c|c|c|c|}
\hline \multirow{2}{*}{$\begin{array}{l}\text { Excess Returns } \\
\rightarrow \\
\text { Int. Diffs } \downarrow\end{array}$} & \multicolumn{2}{|c|}{$\begin{array}{l}\text { 1.Excess Return } \\
\qquad l^{\prime} u\end{array}$} & \multicolumn{2}{|c|}{$\begin{array}{l}\text { 2.Expected ST Return } \\
\text { Innovation } \\
e 1^{\prime} \Phi(k) u\end{array}$} & \multicolumn{2}{|c|}{$\begin{array}{c}\text { 3.Expected LT Return } \\
\text { Innovation } \\
e 1^{\prime}(\Phi-\Phi(k)) u\end{array}$} & \multicolumn{2}{|c|}{$\begin{array}{c}\text { 4.Cash Flow Innovation } \\
\text { (sum of columns 1-3) } \\
e 1^{\prime} \Psi u\end{array}$} \\
\hline & Majors & All & Majors & All & Majors & All & Majors & All \\
\hline $\begin{array}{l}\text { 1. Unexpected } \\
\text { Change } \\
e 3^{\prime} u\end{array}$ & \multicolumn{2}{|c|}{$\begin{array}{l}\text { Price Impact } \\
\qquad e 1^{\prime} \Sigma e 3\end{array}$} & \multicolumn{2}{|c|}{$\begin{array}{l}\text { ST Anticipation } \\
\qquad 1^{\prime} \Phi(k) \Sigma e 3\end{array}$} & \multicolumn{2}{|c|}{$\begin{array}{c}\text { LT Anticipation } \\
e 1^{\prime}(\Phi-\Phi(k)) \sum e 3\end{array}$} & \multicolumn{2}{|c|}{$\begin{array}{l}\text { Total Price Impact } \\
\qquad e 1^{\prime} \Psi \Sigma e 3\end{array}$} \\
\hline $\begin{array}{l}\text { 2. Expected ST Int. } \\
\text { Diff Innovation } \\
e 3^{\prime} \Phi(k) u\end{array}$ & \multicolumn{2}{|c|}{$\begin{array}{l}\text { ST Trend Chasing } \\
e 1^{\prime} \Sigma \Phi(k)^{\prime} e 3\end{array}$} & \multicolumn{2}{|c|}{$\begin{array}{l}\text { ST Expectational Comovement } \\
\qquad e 1^{\prime} \Phi(k) \Sigma \Phi(k)^{\prime} e 3\end{array}$} & \multicolumn{2}{|c|}{$\begin{array}{l}\text { Expectational Comovement } \\
e 1^{\prime}(\Phi-\Phi(k)) \Sigma \Phi(k)^{\prime} e 3\end{array}$} & \multicolumn{2}{|c|}{$\begin{array}{c}\text { ST Cash Flow Chasing } \\
\qquad 1^{\prime} \Psi \Sigma \Phi(k)^{\prime} e 3\end{array}$} \\
\hline $\begin{array}{l}\text { 3. Expected LT Int. } \\
\text { Diff Innovation } \\
e 3^{\prime}(\Phi-\Phi(k)) u\end{array}$ & $\begin{array}{l}29.273 \\
25.393\end{array}$ & $\begin{array}{l}5.948 \\
6.112\end{array}$ & $\begin{array}{l}0.503 \\
2.445\end{array}$ & $\begin{array}{l}1.452 \\
1.707\end{array}$ & $\begin{array}{r}-27.749 \\
28.571\end{array}$ & $\begin{array}{c}-4.869 \\
6.316\end{array}$ & $\begin{array}{r}2.027 \\
13.414\end{array}$ & $\begin{array}{l}2.531 \\
1.511\end{array}$ \\
\hline \multirow{2}{*}{$\begin{array}{c}\text { 4. Total Int. Diff. } \\
\text { Innovation (sum) } \\
\qquad e 3^{\prime} \Psi u\end{array}$} & \multicolumn{2}{|c|}{$e 1^{\prime} \Sigma \Psi^{\prime} e 3$} & \multicolumn{2}{|c|}{$e 1^{\prime} \Phi(k) \Sigma \Psi^{\prime} e 3$} & \multicolumn{2}{|c|}{$e 1^{\prime}(\Phi-\Phi(k)) \Sigma \Psi^{\prime} e 3$} & \multicolumn{2}{|c|}{$e 1^{\prime} \Psi \Sigma \Psi^{\prime} e 3$} \\
\hline & $\begin{array}{l}31.116 \\
25.366\end{array}$ & $\begin{array}{l}6.981 \\
6.218\end{array}$ & $\begin{array}{l}0.809 \\
2.719\end{array}$ & $\begin{array}{l}3.146 \\
2.527\end{array}$ & $\begin{array}{r}-29.022 \\
29.321\end{array}$ & $\begin{array}{r}-5.142 \\
6.559\end{array}$ & $\begin{array}{r}2.904 \\
14.909\end{array}$ & $\begin{array}{l}4.985 \\
2.298\end{array}$ \\
\hline
\end{tabular}


Table 6: Relationships Between Interest Differentials and Returns in a Fundamentals-only VAR

Table 6 summarizes the relationships between Returns and Interest Differentials obtained from a VAR containing Excess Returns, Interest Differentials and Real Exchange Rates. We first present interpretations of the various elements of the relationship matrix, followed by the estimates themselves. To scale the covariances, we divide each measure by $\left(e 1^{\prime} \Sigma e 1 e 3^{\prime} \Sigma e 3\right)^{1 / 2}$, the product of the innovation standard deviations. Standard errors are below coefficients in italics.

\begin{tabular}{|c|c|c|c|c|c|c|c|c|}
\hline \multirow{2}{*}{$\begin{array}{l}\text { Excess Returns } \\
\rightarrow \\
\text { Int. Diffs } \downarrow\end{array}$} & \multicolumn{2}{|c|}{$\begin{array}{l}\text { 1.Excess Return } \\
e 1^{\prime} u\end{array}$} & \multicolumn{2}{|c|}{$\begin{array}{l}\text { 2.Expected ST Return } \\
\text { Innovation } \\
e 1^{\prime} \Phi(k) u\end{array}$} & \multicolumn{2}{|c|}{$\begin{array}{c}\text { 3.Expected LT Return } \\
\text { Innovation } \\
e 1^{\prime}(\Phi-\Phi(k)) u\end{array}$} & \multicolumn{2}{|c|}{$\begin{array}{c}\text { 4.Cash Flow Innovation } \\
\text { (sum of columns 1-3) } \\
e 1^{\prime} \Psi u\end{array}$} \\
\hline & Majors & All & Majors & All & Majors & All & Majors & All \\
\hline \multirow[t]{2}{*}{$\begin{array}{l}\text { 1. Unexpected Change } \\
\qquad 3^{\prime} u\end{array}$} & \multicolumn{2}{|c|}{$\begin{array}{l}\text { Price Impact } \\
\qquad e 1^{\prime} \Sigma e 3\end{array}$} & \multicolumn{2}{|c|}{$\begin{array}{l}\text { ST Anticipation } \\
e 1^{\prime} \Phi(k) \sum e 3\end{array}$} & \multicolumn{2}{|c|}{$\begin{array}{c}\text { LT Anticipation } \\
e 1^{\prime}(\Phi-\Phi(k)) \Sigma e 3\end{array}$} & \multicolumn{2}{|c|}{$\begin{array}{l}\text { Total Price Impact } \\
\qquad e 1^{\prime} \Psi \Sigma e 3\end{array}$} \\
\hline & $\begin{array}{l}0.007 \\
0.009\end{array}$ & $\begin{array}{l}0.002 \\
0.015\end{array}$ & $\begin{array}{l}0.013 \\
0.056\end{array}$ & $\begin{array}{l}0.078 \\
0.096\end{array}$ & $\begin{array}{l}0.016 \\
0.070\end{array}$ & $\begin{array}{l}0.037 \\
0.085\end{array}$ & $\begin{array}{l}0.036 \\
0.055\end{array}$ & $\begin{array}{l}0.117 \\
0.035\end{array}$ \\
\hline \multirow{2}{*}{$\begin{array}{l}\text { 2. Expected ST Int. } \\
\text { Diff Innovation } \\
e 3^{\prime} \Phi(k) u\end{array}$} & \multicolumn{2}{|c|}{$\begin{array}{l}\text { ST Trend Chasing } \\
\qquad e 1^{\prime} \Sigma \Phi(k)^{\prime} e 3\end{array}$} & \multicolumn{2}{|c|}{$\begin{array}{c}\text { ST Expectational Comovement } \\
\qquad e 1^{\prime} \Phi(k) \Sigma \Phi(k)^{\prime} e 3\end{array}$} & \multicolumn{2}{|c|}{$\begin{array}{l}\text { Expectational Comovement } \\
e 1^{\prime}(\Phi-\Phi(k)) \Sigma \Phi(k)^{\prime} e 3\end{array}$} & \multicolumn{2}{|c|}{$\begin{array}{l}\text { ST Cash Flow Chasing } \\
\qquad e 1^{\prime} \Psi \Sigma \Phi(k)^{\prime} e 3\end{array}$} \\
\hline & $\begin{array}{l}1.858 \\
0.785\end{array}$ & $\begin{array}{l}1.017 \\
0.982\end{array}$ & $\begin{array}{l}0.249 \\
0.939\end{array}$ & $\begin{array}{l}1.610 \\
1.763\end{array}$ & $\begin{array}{r}-1.201 \\
1.760\end{array}$ & $\begin{array}{r}-0.294 \\
1.791\end{array}$ & $\begin{array}{l}0.906 \\
1.519\end{array}$ & $\begin{array}{l}2.334 \\
0.707\end{array}$ \\
\hline \multirow{2}{*}{$\begin{array}{l}\text { 3. Expected LT Int. } \\
\text { Diff Innovation } \\
e 3^{\prime}(\Phi-\Phi(k)) u\end{array}$} & \multicolumn{2}{|c|}{$\begin{array}{l}\text { LT Trend Chasing } \\
e 1^{\prime} \Sigma(\Phi-\Phi(k))^{\prime} e 3\end{array}$} & \multicolumn{2}{|c|}{$\begin{array}{l}\text { Expectational Comovement } \\
e 1^{\prime} \Phi(k) \Sigma(\Phi-\Phi(k))^{\prime} e 3\end{array}$} & \multicolumn{2}{|c|}{$\begin{array}{l}\text { LT Expectational Comovement } \\
\qquad 1^{\prime}(\Phi-\Phi(k)) \Sigma(\Phi-\Phi(k))^{\prime} e 3\end{array}$} & \multicolumn{2}{|c|}{$\begin{array}{l}\text { LT Cash Flow Chasing } \\
e 1^{\prime} \Psi \Sigma(\Phi-\Phi(k))^{\prime} e 3\end{array}$} \\
\hline & $\begin{array}{l}30.090 \\
27.081\end{array}$ & $\begin{array}{l}5.828 \\
9.293\end{array}$ & $\begin{array}{l}0.357 \\
2.296\end{array}$ & $\begin{array}{l}1.520 \\
2.050\end{array}$ & $\begin{array}{r}-28.413 \\
29.177\end{array}$ & $\begin{array}{r}-4.808 \\
9.175\end{array}$ & $\begin{array}{r}2.033 \\
13.604\end{array}$ & $\begin{array}{l}2.540 \\
2.162\end{array}$ \\
\hline \multirow{2}{*}{$\begin{array}{l}\text { 4. Total Int. Diff. } \\
\text { Innovation (sum) } \\
\qquad e 3^{\prime} \Psi u\end{array}$} & \multicolumn{2}{|c|}{$e 1^{\prime} \Sigma \Psi{ }^{\prime} e 3$} & \multicolumn{2}{|c|}{$e 1^{\prime} \Phi(k) \Sigma \Psi^{\prime} e 3$} & \multicolumn{2}{|c|}{$e 1^{\prime}(\Phi-\Phi(k)) \Sigma \Psi^{\prime} e 3$} & \multicolumn{2}{|c|}{$e 1^{\prime} \Psi \Sigma \Psi^{\prime} e 3$} \\
\hline & $\begin{array}{l}31.955 \\
27.055\end{array}$ & $\begin{array}{l}6.847 \\
9.345\end{array}$ & $\begin{array}{l}0.619 \\
2.595\end{array}$ & $\begin{array}{l}3.209 \\
3.284\end{array}$ & $\begin{array}{r}-29.599 \\
29.813\end{array}$ & $\begin{array}{r}-5.065 \\
9.348\end{array}$ & $\begin{array}{r}2.975 \\
15.042\end{array}$ & $\begin{array}{l}4.991 \\
2.656\end{array}$ \\
\hline
\end{tabular}


Table 7: Relationships Between Interest Differentials and Flows

Table 7 summarizes the relationships between Flows and Interest Differentials using the cash flow and expected return decomposition obtained from our VAR estimates. We present interpretations of the various elements of the relationship matrix, followed by the estimates themselves. To scale the covariances, we divide each measure by $\left(e 2^{\prime} \Sigma e 2 e 3^{\prime} \Sigma e 3\right)^{1 / 2}$, the product of the innovation standard deviations. Standard errors are below coefficients in italics.

\begin{tabular}{|c|c|c|c|c|c|c|c|c|}
\hline \multirow[t]{2}{*}{$\begin{array}{l}\text { Flows } \rightarrow \\
\text { Int.Diffs } \downarrow\end{array}$} & \multicolumn{2}{|c|}{$\begin{array}{l}\text { 1.Unexpected Flow } \\
\qquad 2^{\prime} u\end{array}$} & \multicolumn{2}{|c|}{$\begin{array}{l}\text { 2.Expected ST Flow } \\
\text { Innovation } \\
e 2^{\prime} \Phi(k) u\end{array}$} & \multicolumn{2}{|c|}{$\begin{array}{l}\text { 3.Expected LT Flow Innovation } \\
e 2^{\prime}(\Phi-\Phi(k)) u\end{array}$} & \multicolumn{2}{|c|}{$\begin{array}{c}\text { 4. Total Flow Innovation } \\
\text { (sum of columns 1-3) } \\
e 2^{\prime} \Psi u\end{array}$} \\
\hline & Majors & All & Majors & All & Majors & All & Majors & All \\
\hline \multirow{2}{*}{$\begin{array}{l}\text { 1. Unexpected Change } \\
\qquad 3^{\prime} u\end{array}$} & \multicolumn{2}{|c|}{$\begin{array}{l}\text { Comovement } \\
\qquad 2^{\prime} \Sigma e 3\end{array}$} & \multicolumn{2}{|c|}{$\begin{array}{l}\text { ST Flows Respond to Int.Diff } \\
\qquad e 2^{\prime} \Phi(k) \Sigma e 3\end{array}$} & \multicolumn{2}{|c|}{$\begin{array}{l}\text { LT Flows Respond to Int.Diff } \\
\qquad e 2^{\prime}(\Phi-\Phi(k)) \Sigma e 3\end{array}$} & \multicolumn{2}{|c|}{$\begin{array}{l}\text { Total Flow Response } \\
\qquad 2^{\prime} \Psi \Sigma e 3\end{array}$} \\
\hline & $\begin{array}{l}0.009 \\
0.008\end{array}$ & $\begin{array}{l}0.002 \\
0.003\end{array}$ & $\begin{array}{r}-0.033 \\
0.094\end{array}$ & $\begin{array}{l}0.015 \\
0.047\end{array}$ & $\begin{array}{l}-0.118 \\
0.192\end{array}$ & $\begin{array}{l}0.016 \\
0.209\end{array}$ & $\begin{array}{r}-0.141 \\
0.193\end{array}$ & $\begin{array}{l}0.033 \\
0.220\end{array}$ \\
\hline \multirow{2}{*}{$\begin{array}{l}\text { 2. Expected ST Int. } \\
\text { Diff Innovation } \\
e 3^{\prime} \Phi(k) u\end{array}$} & \multicolumn{2}{|c|}{$\begin{array}{l}\text { Flows Anticipate ST Int. Diff } \\
\qquad e 2^{\prime} \Sigma \Phi(k)^{\prime} e 3\end{array}$} & \multicolumn{2}{|c|}{$\begin{array}{l}\text { ST Expectational Comovement } \\
\qquad 2^{\prime} \Phi(k) \Sigma \Phi(k)^{\prime} e 3\end{array}$} & \multicolumn{2}{|c|}{$\begin{array}{l}\text { Expectational Comovement } \\
e 2^{\prime}(\Phi-\Phi(k)) \Sigma \Phi(k)^{\prime} e 3\end{array}$} & \multicolumn{2}{|c|}{$e 2^{\prime} \Psi \Sigma \Phi(k)^{\prime} e 3$} \\
\hline & $\begin{array}{l}2.066 \\
1.027\end{array}$ & $\begin{array}{l}0.528 \\
0.287\end{array}$ & $\begin{array}{l}0.633 \\
1.607\end{array}$ & $\begin{array}{l}0.738 \\
0.890\end{array}$ & $\begin{array}{r}-4.330 \\
4.974\end{array}$ & $\begin{array}{l}1.253 \\
4.166\end{array}$ & $\begin{array}{r}-1.630 \\
5.207\end{array}$ & $\begin{array}{l}2.520 \\
4.377\end{array}$ \\
\hline \multirow{2}{*}{$\begin{array}{l}\text { 3. Expected LT Int. } \\
\text { Diff Innovation } \\
e 3^{\prime}(\Phi-\Phi(k)) u\end{array}$} & \multicolumn{2}{|c|}{$\begin{array}{l}\text { Flows Anticipate LT Int. Diff } \\
\qquad e 2^{\prime} \Sigma(\Phi-\Phi(k))^{\prime} e 3\end{array}$} & \multicolumn{2}{|c|}{$\begin{array}{l}\text { Expectational Comovement } \\
e 2^{\prime} \Phi(k) \Sigma(\Phi-\Phi(k))^{\prime} e 3\end{array}$} & \multicolumn{2}{|c|}{$\begin{array}{l}\text { LT Expectational Comovement } \\
e 2^{\prime}(\Phi-\Phi(k)) \Sigma(\Phi-\Phi(k))^{\prime} e 3\end{array}$} & \multicolumn{2}{|c|}{$e 2^{\prime} \Psi \Sigma(\Phi-\Phi(k))^{\prime} e 3$} \\
\hline & $\begin{array}{l}10.241 \\
10.372\end{array}$ & $\begin{array}{r}-0.431 \\
1.607\end{array}$ & $\begin{array}{l}9.303 \\
9.107\end{array}$ & $\begin{array}{l}0.256 \\
1.669\end{array}$ & $\begin{array}{c}-44.333 \\
67.589\end{array}$ & $\begin{array}{l}3.770 \\
7.406\end{array}$ & $\begin{array}{r}-24.789 \\
51.778\end{array}$ & $\begin{array}{l}3.595 \\
9.877\end{array}$ \\
\hline \multirow{2}{*}{$\begin{array}{l}\text { 4. Total Int. Diff. } \\
\text { Innovation (sum) } \\
\qquad e 3^{\prime} \Psi u\end{array}$} & \multicolumn{2}{|c|}{$\begin{array}{l}\text { Total Anticipation of Int. Diff } \\
\qquad e 2^{\prime} \Sigma \Psi^{\prime} e 3\end{array}$} & \multicolumn{2}{|c|}{$e 2^{\prime} \Phi(k) \Sigma \Psi^{\prime} e 3$} & \multicolumn{2}{|c|}{$e 2^{\prime}(\Phi-\Phi(k)) \Sigma \Psi^{\prime} e 3$} & \multicolumn{2}{|c|}{$e 2^{\prime} \Psi \Sigma \Psi^{\prime} e 3$} \\
\hline & $\begin{array}{l}12.317 \\
10.315\end{array}$ & $\begin{array}{l}0.098 \\
1.685\end{array}$ & $\begin{array}{l}9.904 \\
9.180\end{array}$ & $\begin{array}{l}1.009 \\
2.050\end{array}$ & $\begin{array}{r}-48.780 \\
71.672\end{array}$ & $\begin{array}{l}5.040 \\
10.435\end{array}$ & $\begin{array}{r}-26.560 \\
56.295\end{array}$ & $\begin{array}{r}6.148 \\
12.682\end{array}$ \\
\hline
\end{tabular}


Figure 1: Contemporaneous Correlation of Flows and Returns
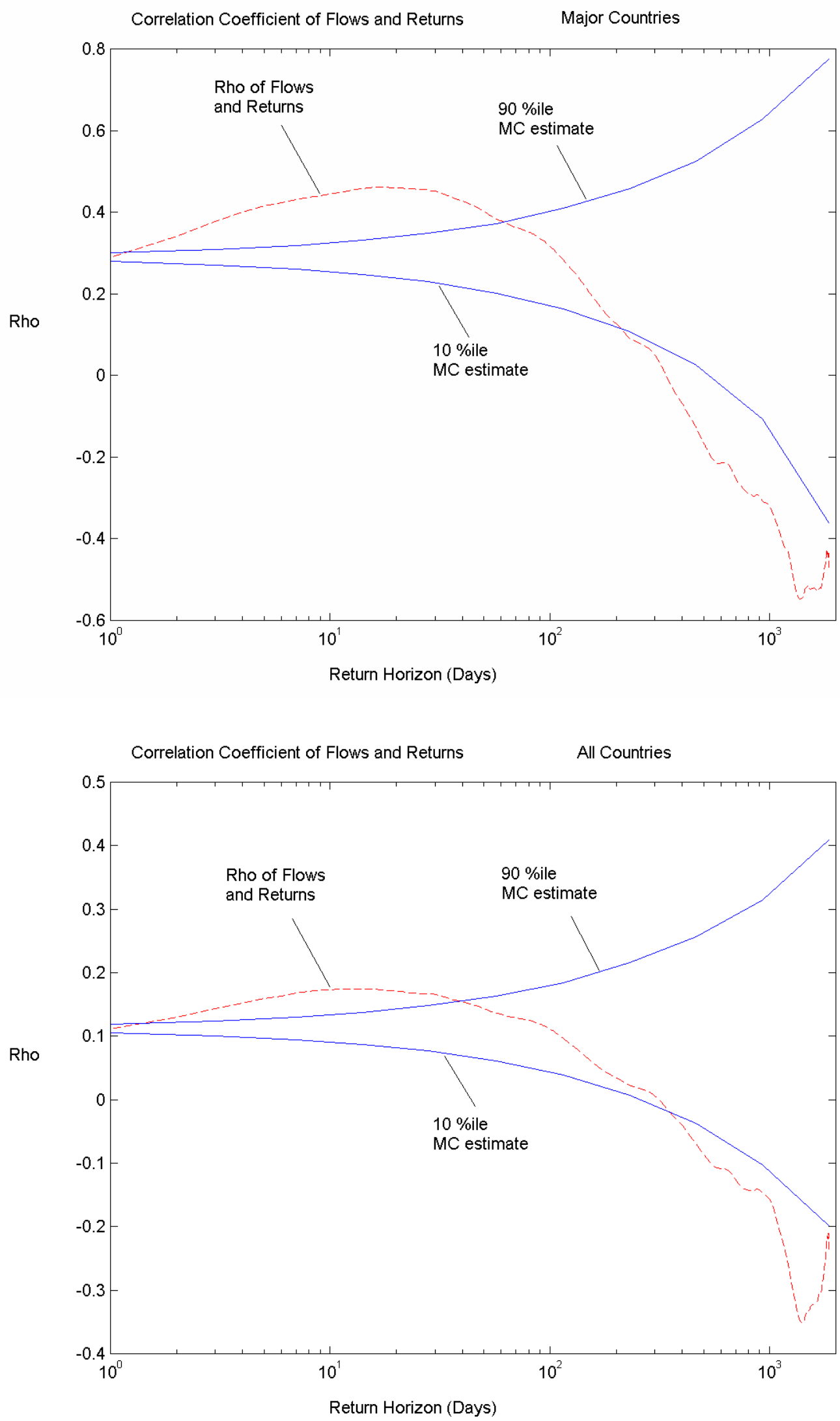
Figure 2a-Cumulative Excess Returns - Majors

Excess Return Impulse Response to a 50bp Shock to Cash Flows

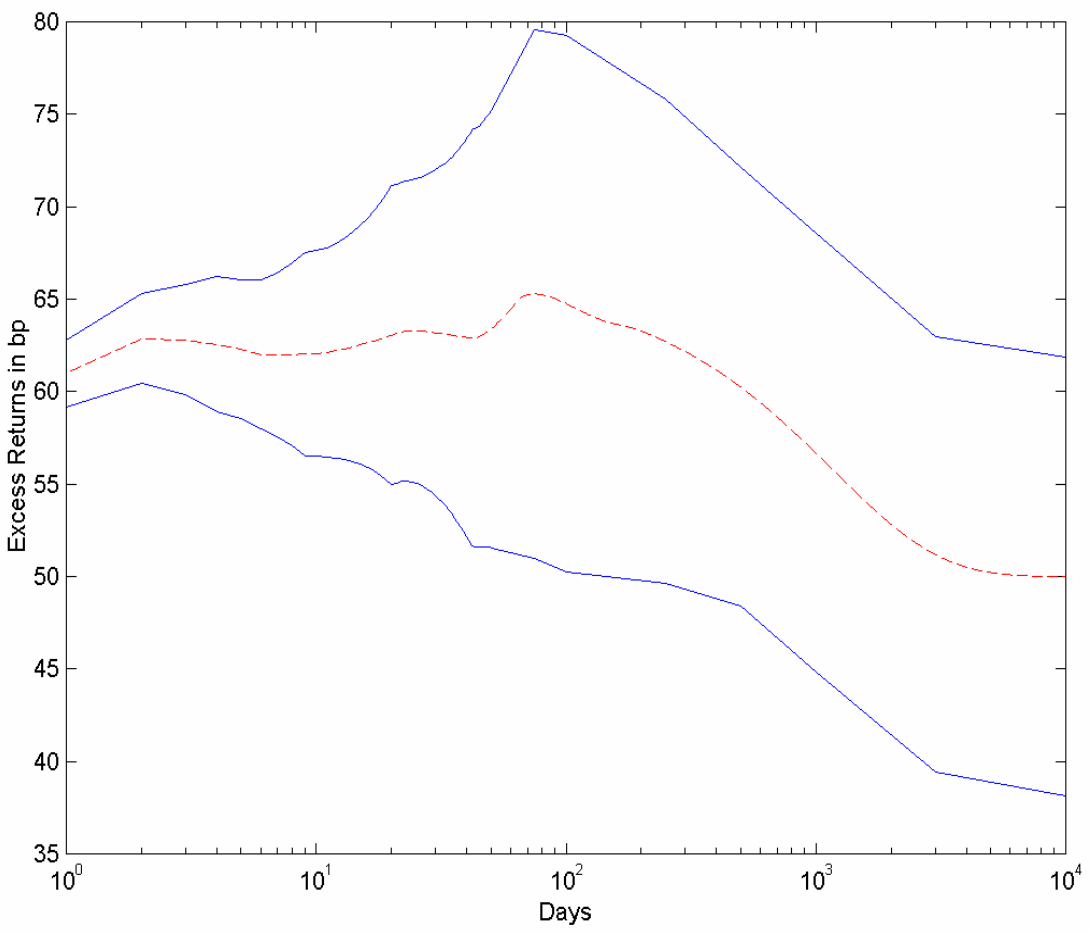

Figure 2b - Cumulative Excess Returns - All Countries

Excess Return Impulse Response to a 50bp Shock to Cash Flows

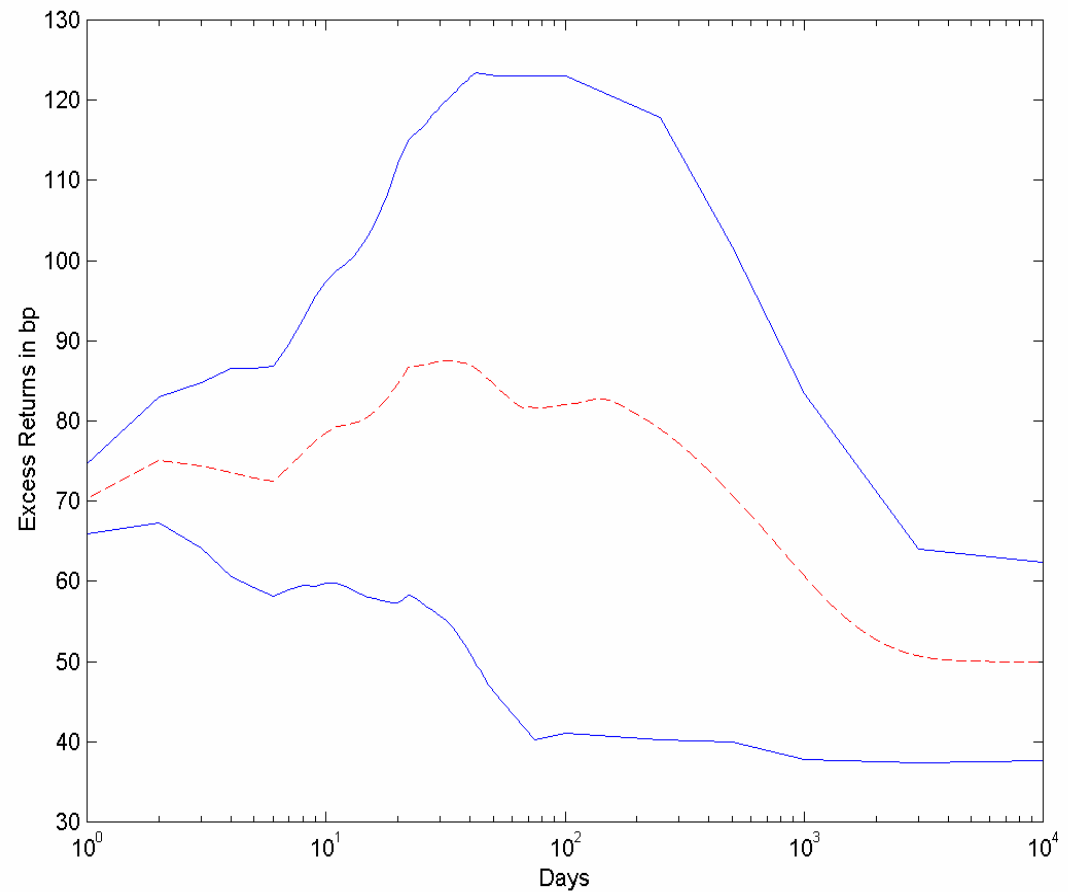


Figure 3a - Cumulative Excess Returns- Majors

Excess Return Impulse Response to a 50bp shock to Expected Returns

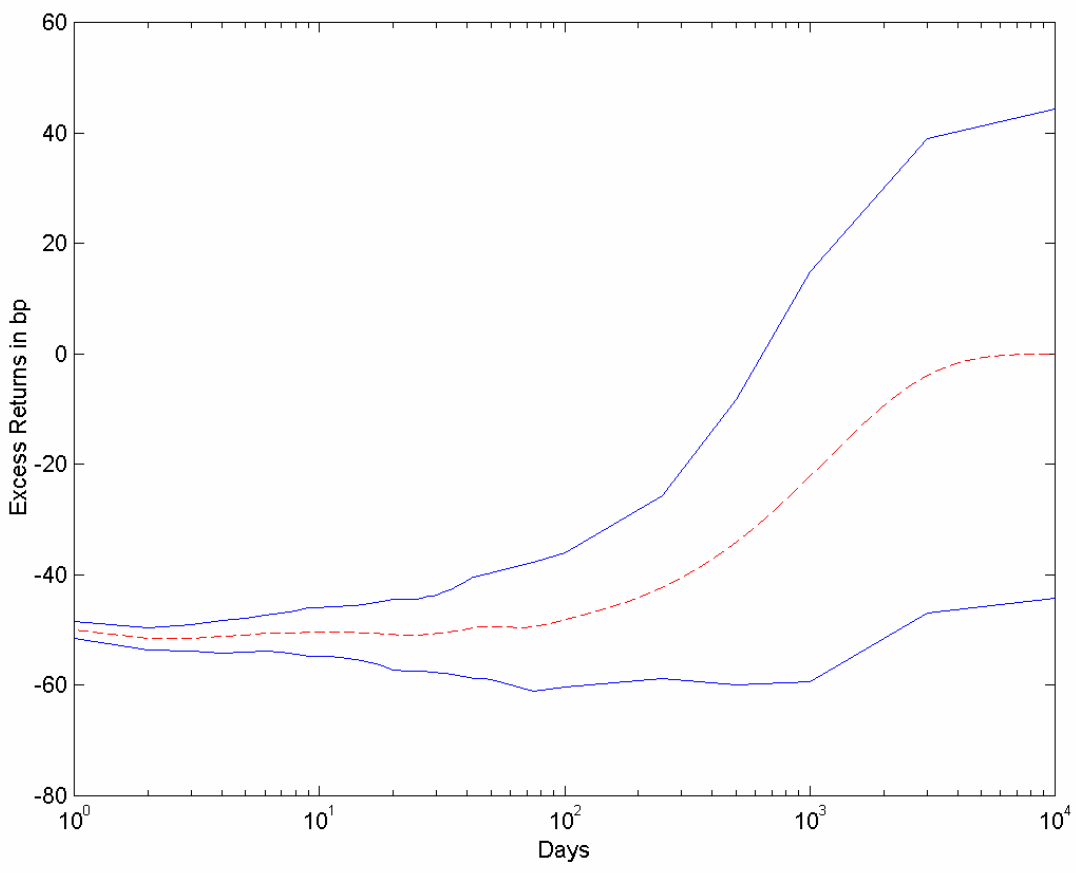

Figure 3b-Cumulative Excess Returns-All Countries

Excess Return Impulse Response to a 50bp shock to Expected Returns

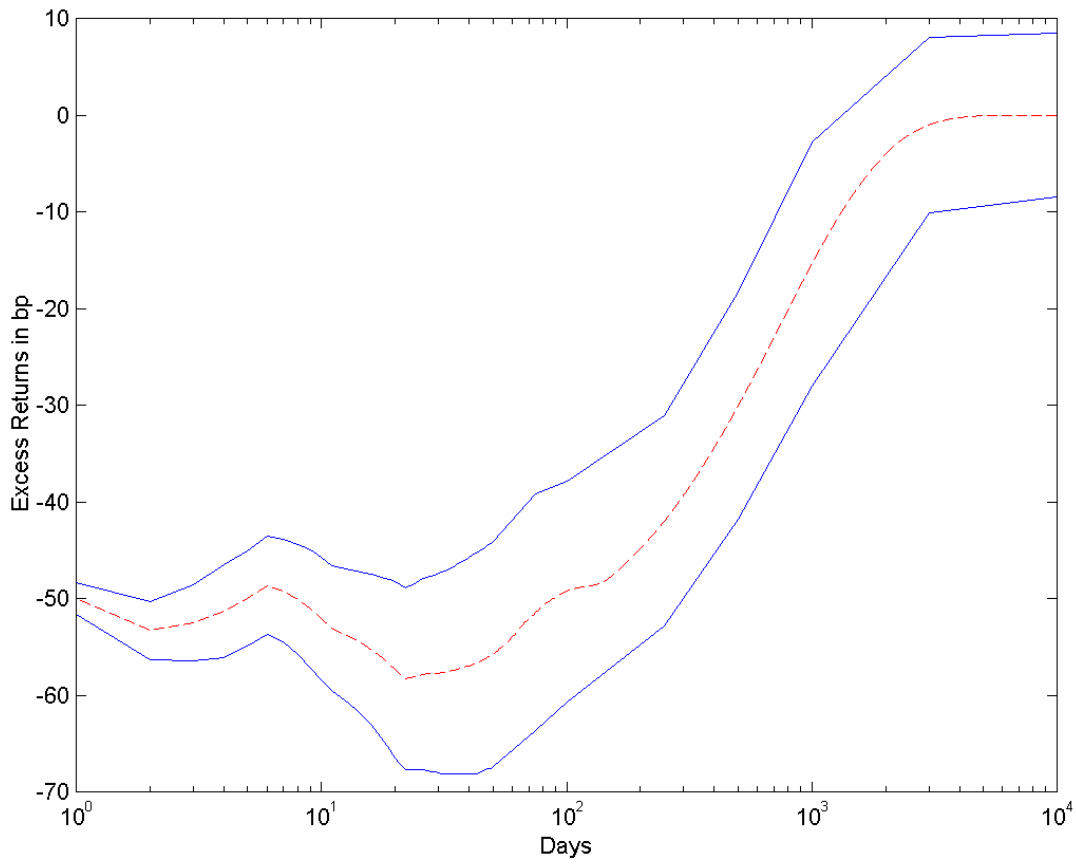


Figure 4a-Cumulative Currency Flows- Majors

Flow Impulse Response to a 50bp shock to Cash Flows

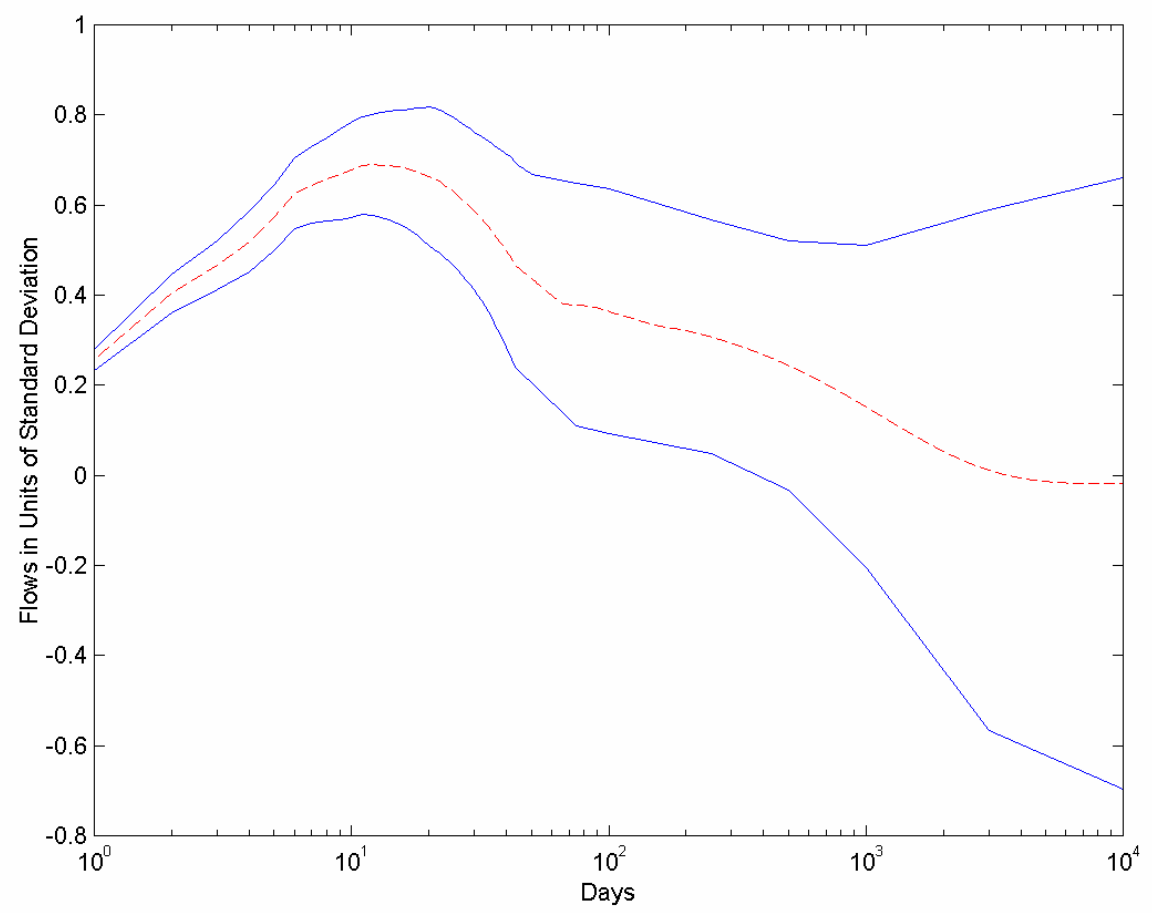

Figure 4b-Cumulative Currency Flows-All Countries Flow Impulse Response to a 50bp shock to Cash Flows

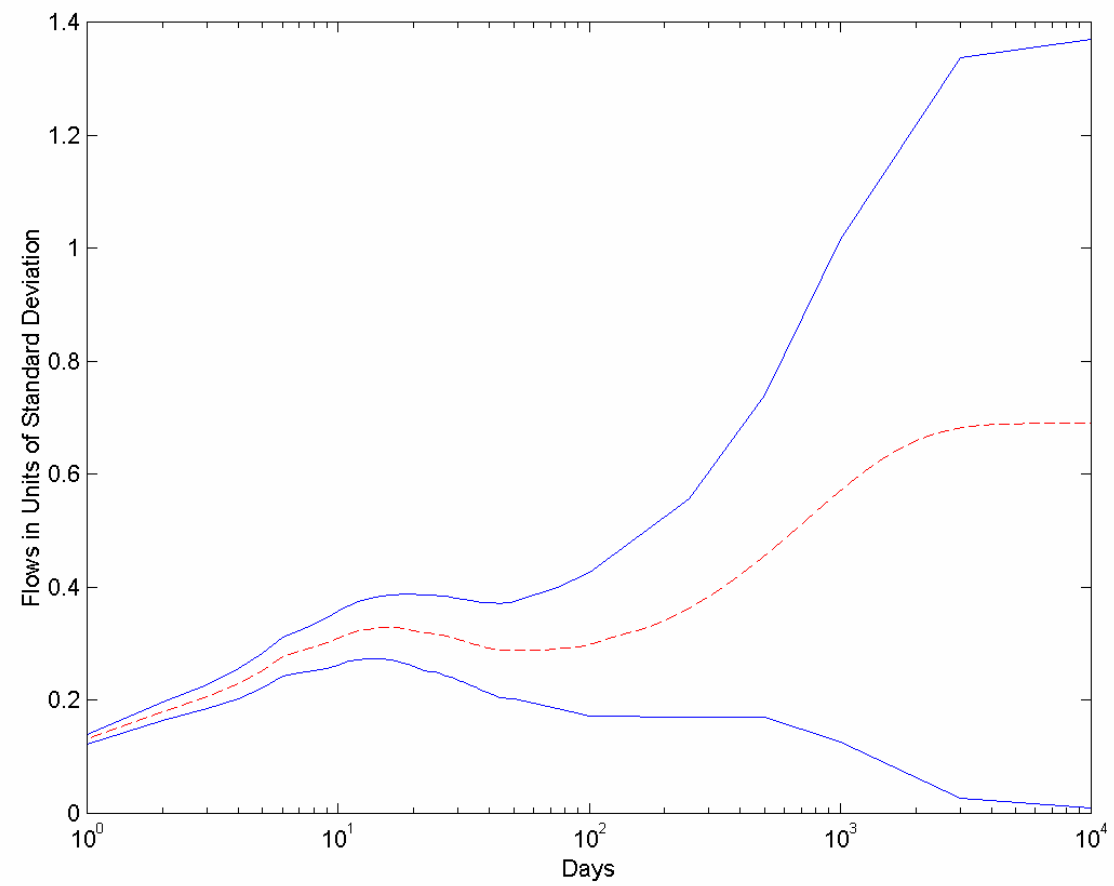


Figure 5a-Cumulative Currency Flows- Majors

Flow Impulse Response to a Zero Cash Flow Appreciation from Short Run Expected Returns

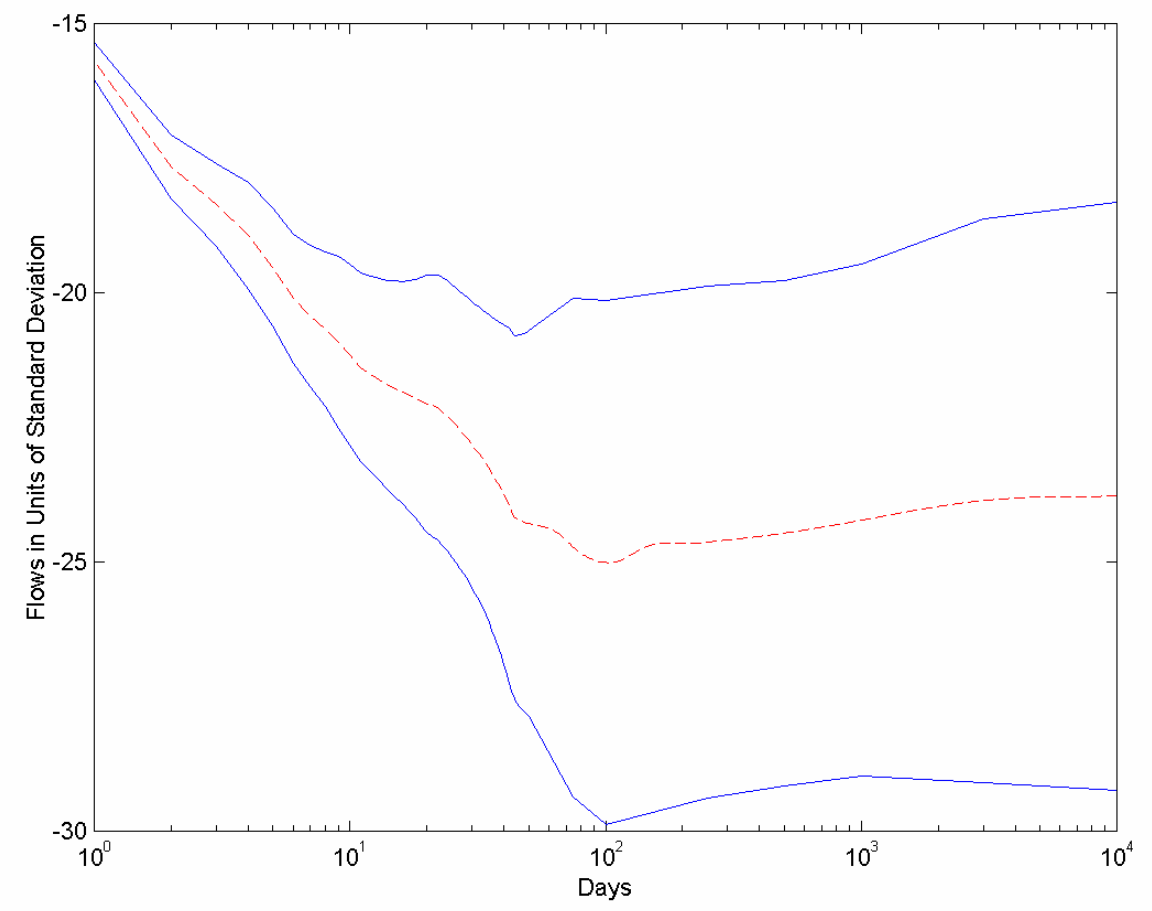

Figure 5b - Cumulative Currency Flows- All Countries

Flow Impulse Response to a Zero Cash Flow Appreciation from Short Run Expected Returns

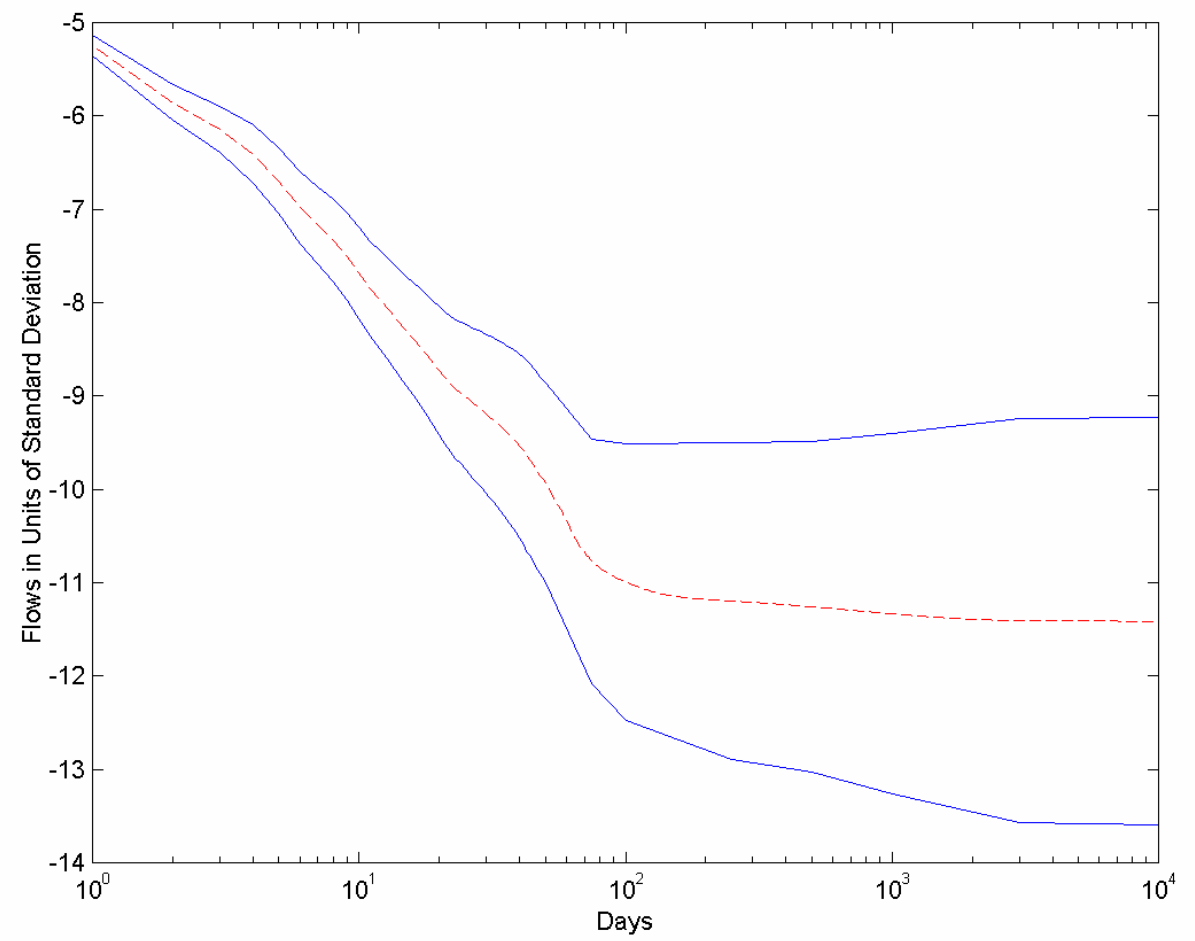


Figure 6a-Cumulative Currency Flows- Majors

Flow Impulse Response to a Zero Cash Flow Appreciation from Long Run Expected Returns

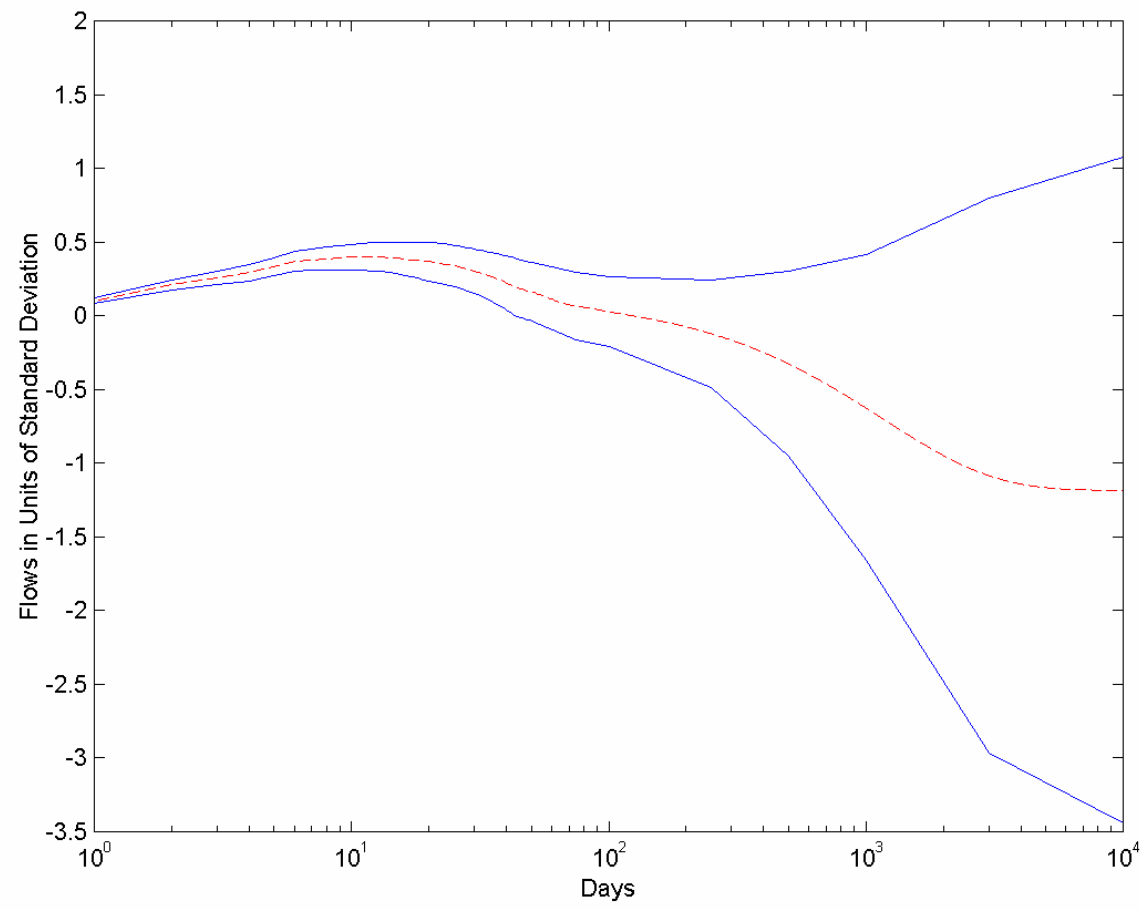

Figure 6b-Cumulative Currency Flows- All Countries

Flow Impulse Response to a Zero Cash Flow Appreciation from Long Run Expected Returns

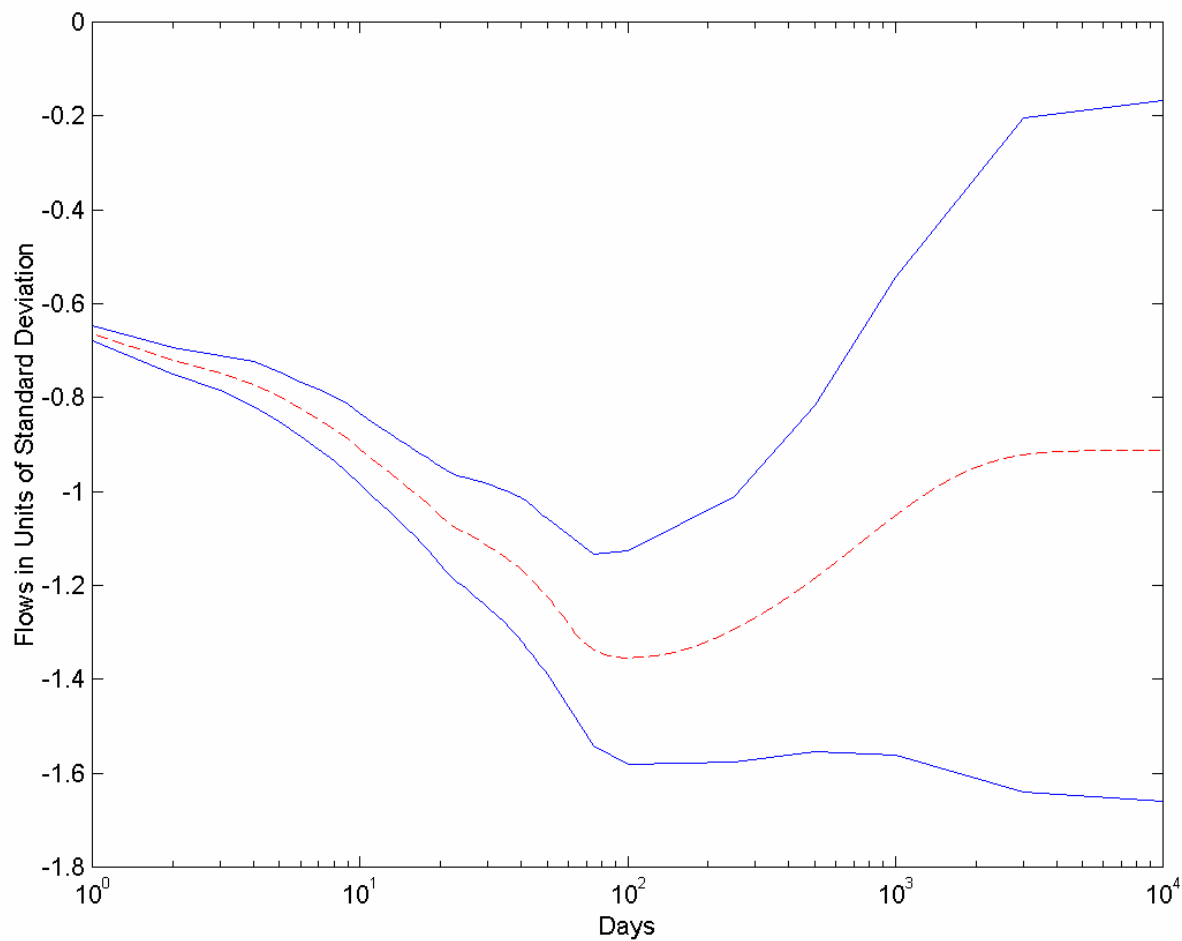


Figure 7a - Cumulative Excess Returns- Major Countries

Excess Return Impulse Response to a 1 Standard Deviation Shock to Flows

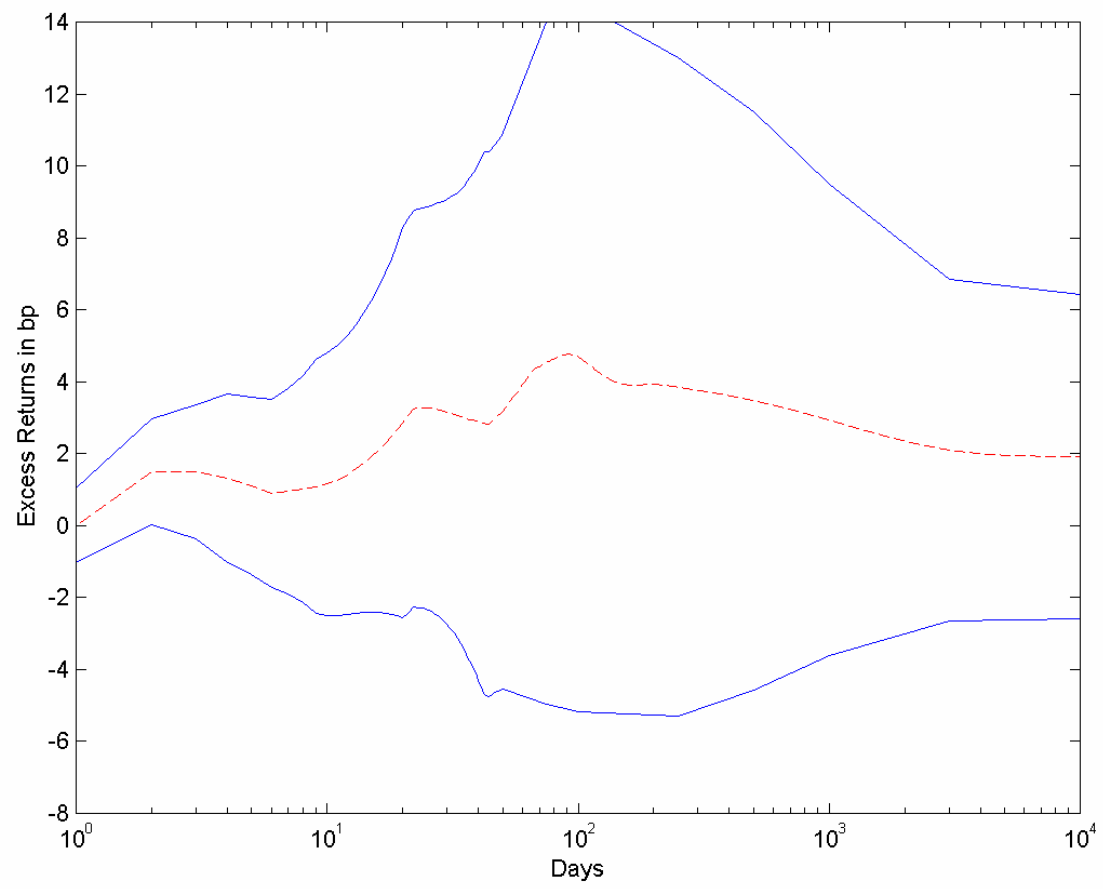

Figure 7b - Cumulative Excess Returns-All Countries Excess Return Impulse Response to a 1 Standard Deviation Shock to Flows

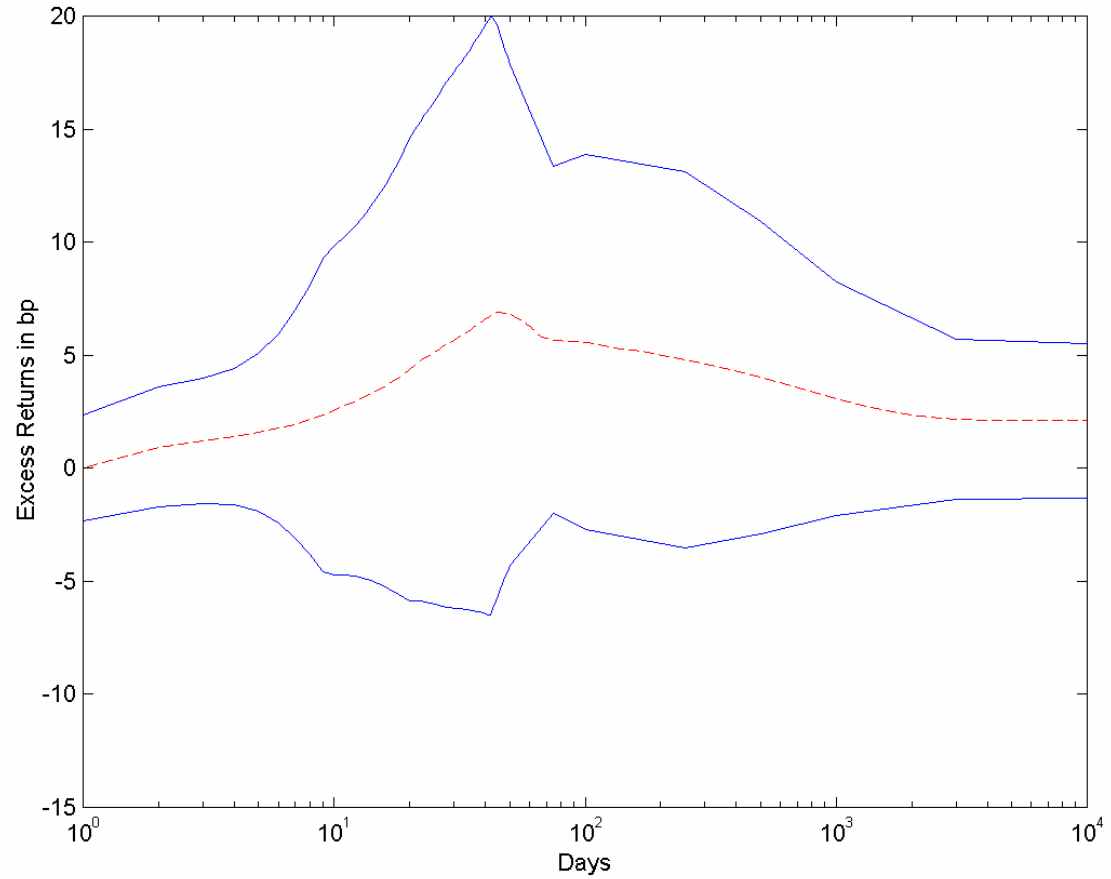

